\title{
The Acisted Eye: \\ Transgender and Intersex Bodies in International \\ Cis-Authored Film and Television
}

by

Evan Read Armstrong

A thesis submitted to the Faculty of Graduate and Postdoctoral Affairs in partial fulfillment of the requirements for the degree of

Master of Arts

in

Film Studies

Carleton University

Ottawa, Ontario

(C) 2016, Evan Read Armstrong 


\begin{abstract}
Dealing with the politics of representation, this thesis examines the implications of mainstream media depicting minority bodies. Contemporary North American media is inundated with images of transgender bodies. But who is depicting these bodies and how are they directing the spectator to look and listen to the transgender or intersex protagonist? This thesis explores the different ways in which contemporary cisgender filmmakers in Australia, France, the United States and Uruguay encourage spectators to understand the transgender body, while counterbalancing this analysis with a depictions of an intersex experience. By analyzing three different modes of fashioning the transgender and intersex protagonists (through self-representation, by the camera and production by the diegetic home) the formation of identities can be firmly mapped. This thesis uses close visual analysis in relation to key theories in trans scholarship to understand how transgender and intersex bodies are being fictionally represented by their cisgender counterparts.
\end{abstract}




\section{Acknowledgements}

This thesis was a labour of love that would not have been possible without the help and support of many different people who I will forever be indebted to. It would be impossible to understate how much they have all helped me in this process:

To Theo, for being my touchstone each week with our writing group, especially in the last few months where it became harder and harder to keep track of what this project was supposed to be. I live for our fifteen minute breaks.

Thank you to Alannah for being my friend, copy-writer extraordinaire and my Joe Biden as well as my roommate. And also for putting up with a dirty house while I wrote this damn thing.

To Matt, Maddi, Dave, Alan and the rest of Film Crew 2.0. Thanks for being the dream team that made me believe I could actually do this. Thank you for making me better by inspiring me with your brilliance. You have pushed me to be smarter and braver.

Thank you to my loves Diane Berezowski, Laurie Jaeger and Barbara Shannon. You are the most beautiful girls in the world. Thank you to the entire faculty and administrative staff that make up the Film Department at Carleton for accepting a kid with an English degree into the fold.

A very special thank you to the Steenbakkers family, without whom I would not have been able to do any of this. Thank you for giving me my own recovery space where I could heal after surgery, and thank you for spending ten thousand hours in Ikea with me. This project would not have been possible without the support of my family and friends, who helped me move to the other end of the country to achieve this crazy dream. Thank you for your unconditional love and support. I also specifically want to thank my parents for raising me to be socially conscious and encouraging me to question. I love you.

There are no adequate words to accurately thank Laura Horak. I met her on my first day at Carleton (which also happened to be her first day at Carleton) and I immediately knew I wanted her to be my supervisor. Two years later, and I can safely say that she has put up with more than any supervisor should have to endure. Thank you for taking my midnight emails and for being a continual source of wisdom on all things LGBTQ2-cinema related. Thank you for clearing up my continually messy mind by editing these pages over and over again until they resembled something akin to a master's thesis. Thank you for putting up with me dropping by your office unannounced and making myself at home. Thank you for lending me the books and films that I would never have discovered otherwise. Thank you for teaching me to never apologize. You have made me a better writer and a better academic. Thank you for pushing me to be clear and concise (a feat which most of the time felt impossible). Thank you for setting such a high bar and believing I could meet it. I can honestly say that I have achieved things that I never thought were possible because of your influence in my life. If not for you, this thesis would have been at least ninety percent puns and poetry references. Also, as promised:

Thank you my dearest Laura,

For listening me ramble about Mikael, Alex and Maura,

If it were not for your incredible brain,

I would have never even heard of James

You are so great my Obi Wan 
Thesis writing was ALMOST fun

You have made me so much wiser

You are the world's best supervisor

Last, I need to thank all the LGBTQ2 youth that I've worked with through my facilitator position at Youth Active Media. Thank you for reminding me that mainstream perceptions of queer people matter, especially when it can affect the way you see yourself. Together, we can change the world. 


\section{Table of Contents}

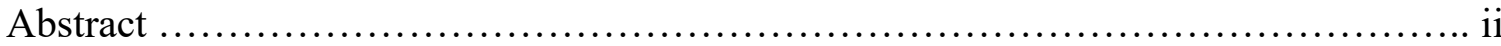

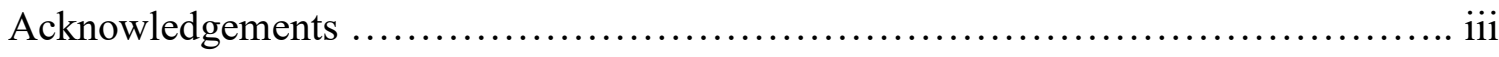

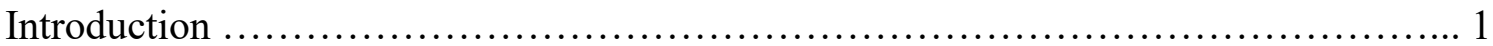

Chapter 1: The Self Made Trans ............................................ 14

Chapter 2: (Re)Envisioning the Trans Body.................................. 42

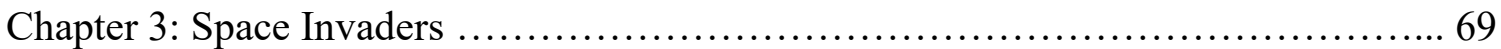

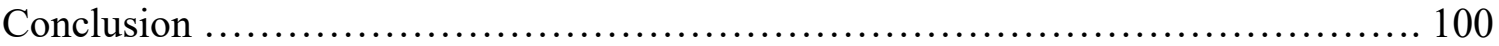

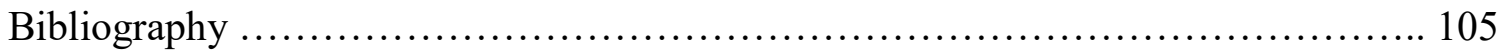

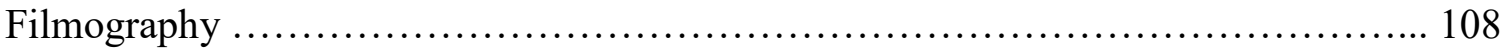




\section{Introduction}

"I stood for a moment between the pains of two violations, the mark of gender and the unlivability of its absence. Could I say which was worse? Or could I only say which one I felt could best be survived?"

- Susan Stryker, "My Words to Victor Frankenstein" (1994)

In 2016, the moment of crisis that Susan Stryker describes above seems more poignant than ever. In the current moment, images of the transgender body are proliferating exponentially in the mainstream. In two years, Caitlyn Jenner began transitioning in the public eye, a dramatic film about Lili Elbe was nominated for an Academy Award, Jazz Jennings (the first famous trans teen in North America) got her own reality show I am Jazz and Laverne Cox was on the cover of Time magazine. In dominant North American culture, trans media is slowly but surely coming to the forefront of the mainstream. Critical scholarship can barely keep up with the rate that it is being produced and distributed. Yet still, in 2015 (the same year Laverne Cox was featured on the cover), anti-trans bathroom laws have proliferated and Time reported that a trans person had died every 29 hours (Steinmetz 1). Somehow as visibility increases in the Western mainstream media, transgender safety is still routinely compromised.

Historically, most trans-related content has been solely produced and represented by cisgender filmmakers who represented trans figures as either victims or villains. Key examples are The Crying Game (1992), Silence of the Lambs (1991) and Boys Don't Cry (1999). However, since 2005 and the creation of YouTube, trans communities have been able to create and distribute their own videos. YouTube's DIY capabilities have allowed trans "vloggers" (video bloggers) to create their own space on the Internet for activism and also for producing their own narratives. As Tobias Raun argues in his dissertation Out Online, "the trans vloggers not only hold on to but claim transsexuality as 
subjectivity" (237). These narratives are lacking in the mainstream media, according to a 2016 survey published by the University of Southern California. From September 2014 to August 2015, out of a sample of 414 mainstream audiovisual works (including film, television and online series) with 11,194 speaking roles, only seven were given to trans characters (Smith, Choueiti and Pieper 111). While cisgender creative authorities are slowly becoming more comfortable using and circulating trans images, trans voices are still being silenced.

When trans and intersex people are being widely represented by cisgender filmmakers, methods of fashioning these bodies must be identified and critiqued. In this thesis, my main research questions are: How do these contemporary cisgender-made films and television shows direct the viewer to look at and listen to the transgender and/or intersex body? What are the political and social ramifications of these aesthetic and narrative strategies? These questions are applied to four contemporary international audio-visual works: Tomboy (France, dir. Céline Sciamma, 2011), XXY (Uruguay, dir. Lucía Puenzo, 2007), 52 Tuesdays (Australia, dir. Sophie Hyde 2013) and the series Transparent (United States, created by Jill Soloway 2014). Collectively, these works demonstrate that a cisgender filmmaker can fashion the intersex or trans body in such a way that it impacts how the spectator understands each character's subjectivity. The argument begins by examining how a character self-fashions their felt identity, before examining the way the camera represents either their felt or assigned gender as their "true" identity. Lastly, I interrogate the way the domestic home space sculpts the protagonist's felt identity, and how they operate both inside and outside of the home. 


\section{Methodology and Scope}

My methodology primarily consists of close audiovisual analysis, in relation to key theories and histories of transgender and intersex representation. This approach allows the contrast of trans experience as it has been lived to public representations of trans lives that are created by (and aimed at) cisgender people.

I chose these specific audiovisual works for several reasons. First, I wanted to focus on films and series that went outside the historic representations of trans figures as either victims (such as Brandon Teena in Boys Don't Cry) or villains (such as Buffalo Bill in Silence of the Lambs). More specifically, I wanted to examine stories that focused less on why the character was transitioning (narratives that have historically resorted to the same "trapped in the wrong body" motif) and more on how they were transitioning. In addition, I decided to focus on narratives that centered on the trans or intersex protagonist interacting with the nuclear families they either emerged from or helped create.

I chose screen works that centered on more or less heteronormative familial dynamics (where a father and mother figure were both featured). In order to focus on inter-familial dynamics, two of the works (Transparent and 52 Tuesdays) have protagonists that are adults (and specifically parents) and the other two protagonists (Mikael in Tomboy and Alex in $X X Y$ ) are children. This was done deliberately so that the analysis could be equally weighted between two transitions that are undertaken by producers of a nuclear home versus two products of a nuclear home that rebel against their assigned genders. More simply, my case studies feature two transitions that happen later in life versus a transition and an intersex experience that occur while gender is still being instilled. I chose works that were produced in five different countries on four 
different continents (the United States, France, Argentina/Uruguay and Australia)

because I wanted to contrast different international experiences of gender, with different stylings of family dynamics.

I deliberately chose fictional films rather than documentaries because I wanted to focus on the fashioning of fictional trans characters by cisgender people. More specifically, I wanted to critique representations where the trans or intersex character was wholly conceived by a cisgender mindset (i.e. not based on an actual person's experience). This was specifically necessary because using a fictional character directly affects the amount of creative control the filmmaker has over their representation (rather than compiling a film of a real subject). Integrating the online series Transparent was important because it is one of the first series' to feature a trans protagonist and the extended format contrasts nicely to the films I will be focusing on. Transparent as an online series is neither television nor film but something in between, and that is how I approach it in this thesis.

My reasons for integrating $X X Y$, which portrays an intersex protagonist, into my predominantly trans analysis were manifold. First, while there is a relative increase of trans work being produced and consumed in the mainstream, the same cannot be said for intersex films, which provide a completely different representation of gender and sex. My thesis contrasts these two experiences of gender and sex. In the trans works the characters are trying to dissuade those around them from looking to their bodies as sites of truth. They are, as Jay Prosser argues, creating a narrative of their lived experience: "Narrative is also a kind of second skin: the story the transsexual must weave around the body in order that this body may be "read"' (101). This is markedly different from $X X Y$, where 
Alex, the intersex protagonist, uses their body as proof that they should be allowed to live in a sex that is "neither" and "both." While the protagonists of the trans works distance themselves from their bodies (which bear the markers of assigned sex and gender) Alex looks to their body as a site of truth in order to validate their subjectivity.

It is also important to acknowledge the limitations of this research. All of the protagonists are light-skinned, able-bodied, middle-class, and hail from Western or South American backgrounds. While my initial research included films from Asia, ultimately I decided that the amount of cultural context necessary would far exceed the guidelines for this thesis.

Last, I must position myself in relation to the works I am studying. As a white, cisgender woman, I have done my utmost to self-reflexively examine my argument in relation to the enormous amount of privilege I hold. However, there are associated limitations to my critique. My position as a middle-class scholar and biases that are influenced by a Western, capitalist, Euro-centric and colonized society inform my critique.

\section{On the Shoulders of Giants}

Trans scholarship has figured heavily in the construction and articulation of this thesis. In particular, Julia Serano's book, Whipping Girl: A Transsexual Woman on Sexism and the Scapegoating of Femininity (2007) has been foundational to my approach. In this book, Serano gives an invaluable account of how trans people (and in particular trans women) have been characterized in the media. She also discusses at great length the concepts of cissexism and cissexual assumption and how women of all backgrounds and identities are discriminated against. Serano defines cissexual assumption as: "When a 
cissexual makes the common, albeit mistaken assumption that the way they experience their physical and subconscious sexes... applies to everyone in the world" (164-65). I rely heavily in this thesis on her analysis of both her experience and historical representations of the past, and balance that analysis against contemporary trans works.

Two trans writers that also sculpted my understanding of the trans-narrative historically and online, respectively, are Jay Prosser and Tobias Raun. In my first chapter, I outline Prosser's theories from his book Second Skins: The Body Narratives of Transsexuality (1998) about the literary trans autobiography as it was affected and produced by a medical discourse. I then contrast it to Tobias Raun's 2012 dissertation, Out Online: Trans Self Representation and Community Building on YouTube, which examines and critiques trans vlogs and their methodologies on YouTube. By working with two of these streams of influence in tandem, it is possible to locate how trans narratives have changed with the creation of new media. Furthermore, it becomes clear how mainstream media bears traces of these changes in representation.

Articles in the journal Transgender Studies Quarterly by Susan Stryker, Kadji Amin and Laura Horak, as well as the entry on intersex parenting by Iain Morland, were valuable in contextualizing my arguments on contemporary screen works. Also the articles in the Transgender Studies Reader by Sandy Stone (in the excerpt from The Empire Strikes Back) and the entry by Judith Halberstam on Silence of the Lambs was enormously helpful in my understanding the different ways in which transgender characters have been represented historically. Viviane K. Namaste's book, Invisible Lives: The Erasure of Transsexual and Transgender People (2000) aided my understanding of the systemic violence and oppression that trans people experience. 
From a film scholarship standpoint, the works of Chris Straayer and Annette Kuhn provided critiques of cross-dressing in mainstream comedies that have each been important in constructing my argument about how the spectator has been traditionally conditioned to look and listen to certain bodies. My analysis takes this a step further by centering on bodies that are transgender, and whose subjectivity is represented credibly to the spectator.

Since the identities and terms that I use are constantly evolving to fit the communities who embody them, my argument must first be prefaced with an unpacking of the words that they adopt. Additionally, it is worthwhile to note that these labels are sometimes contested within the trans community. Despite these limits, included below are a list of definitions so that the reader will understand how I am using each term:

- A transgender person is someone, "who moves away from the gender they were assigned at birth" (Stryker, 2008, 1).

- An individual is misgendered when they are labeled as a gender that does not conform with the gender that they identify with.

- Intersex is, "a general term used for a variety of conditions in which a person is born with a reproductive or sexual anatomy that doesn't seem to fit the typical definition of female or male." ("What Is Intersex?", 1)

- A cisgender person identifies with the gender that conforms to the sex they were assigned at birth (ex. A person with a penis who identifies as a man). "The idea behind the terms is to resist the way that 'woman' or 'man' can mean 'nontransgendered woman' or 'nontransgendered man' by default” (Stryker, 2008, 22). 
- Cissexism is the belief that transsexual's identified genders are inferior to, or less authentic than, those of cissexuals (Serano 12).

- Oppositional sexism is the belief that female and male are rigid, mutually exclusive categories, each possessing a unique and non-overlapping set of attributes (Serano 13).

- Sex refers to the reproductive capacity of a body (whether an individual body produces eggs or sperm) (Stryker, 2008, 8).

- Where sex is biological, gender is a culturally produced category (Stryker, 2008, 11).

- The acronym $L G B T Q 2$ describes collective activism among people who selfidentify as lesbian, gay, bisexual, transgender, transsexual, queer, questioning and two spirited.

Establishing these definitions works to give the reader an equal footing with theorists in my study, as well as providing some necessary context so that the audiovisual works themselves might be understood.

\section{Colliding Screens}

Produced by Amazon in 2014, Transparent is an online series with the first season consisting of ten half-hour episodes. While this thesis exclusively analyzes the first season, the second season of the series was released in 2015. Telling the story of Maura Pfefferman (Jeffrey Tambour), a middle-aged trans woman who comes out to her children and transitions later in life, the series chronicles the impact her coming out has on her adult children Josh (Jay Duplass), Ali (Gaby Hoffmann) and Sarah (Amy Landecker). Featuring interwoven storylines dedicated to the four main characters, 
Transparent is also the story of a big, somewhat dysfunctional Jewish family.

Transparent gains credibility from its creator Jill Soloway who herself is the child of a parent who transitioned later in life (Yuan 1).

52 Tuesdays also focuses on a parent who is undergoing a transition. Shot in Adelaide, Australia in 2013, 52 Tuesdays tells the story of James's (Del Herbert-Jane) transition (a middle-aged parent living in suburbia). Told from the perspective of his teenage daughter, Billie (Tilda Cobham-Hervey), who James sends to live with her father at the beginning of the film, 52 Tuesdays is a tumultuous coming of age story for both James and Billie. The film was shot over the course of a year, every Tuesday without fail, as part of an artistic challenge for filmmaker Sophie Hyde and her team. Additionally, Del Herbert-Jane (who identifies as genderqueer in real life) was undergoing an actual gender transition at the time of filming.

Providing a variation to the parenting theme is the adolescent trans protagonist in Tomboy. The story of a young French family who move to an apartment complex in Lyon, where their eldest daughter starts introducing himself to the other children as a boy, Tomboy takes place over the course of one summer. Made by Céline Sciamma in 2011, Tomboy is predominantly shot by a close parallel of the child's eyeline, which is what makes it so visually striking. Yet despite the fact that the majority of the film takes Mikael's (Zoé Héran) felt gender seriously, in the last moments he is forced back into his assigned name (Laure) and gender by his parents and the other children. Since he introduces himself as Mikael before his assigned name is introduced, and since he constantly chooses masculine alternatives over female ones, in my argument I identify the character by his felt gender (he) and his preferred name (Mikael). 
$X X Y$ also features a protagonist at odds with their parents, but for very different reasons. Directed by Lucía Puenzo in 2007, XXY tells the story of Alex (Inés Efron), an intersex fifteen year old, coming to terms with their intersex status, while their parents initially try to persuade them to choose one sex. Set and shot in Uruguay but produced in Argentina with an Argentinian director, $X X Y$ is the only intersex film that I analyze.

Ultimately, Alex chooses to be both sexes and neither. For this reason then, I have opted to use the pronoun "they/them" when describing Alex, in deference to the identity they assert at the end of the film.

\section{Chapter Layout}

This thesis adopts a tripartite structure, with three chapters that each analyze all four works. Each chapter takes up a different mode of fashioning the body: whether it is produced by the self, directed by the camera or composed by the home.

In Chapter One, "The Self Made Trans," I start by examining the four main streams of discourse- medical (Viviane K Namaste), literary (Jay Prosser), cinematic (Judith Halberstam) and online (Tobias Raun) that have historically impacted trans narratives. From there, I examine the way that each of the protagonists fashion their felt identities in relation to these discourses. Going through each work systematically, I identify the way each character uses costume and makeup, and other strategies they use to enact their felt identities (for example, using their voice to tell their story or turning to surgery). Through pursuit of surgery (James), use of language (Maura), demonstrations of physical ability (Mikael) and attempts at provocation (Alex), each of the protagonists asserts themselves, and fashions their felt gender. 
Chapter Two "(Re)Envisioning the Trans Body," examines the audiovisual form and its construction of the individual protagonist. I begin the chapter by briefly summarizing the scholarship of Annette Kuhn and Chris Straayer, who have analyzed the ways cross-dressing films have conditioned mainstream spectators to look and listen to certain bodies. This is then contrasted with the techniques of online media (examined by Laura Horak), which keep the spectator focused on the vlogger's felt identity. From there, I establish a spectrum of approaches: on one end, the films that fully support the protagonist's felt gender (52 Tuesdays and $X X Y$ ) and on the other end, the films that support the assigned gender (Tomboy and Transparent). Examining the formal elements of each work demonstrates that while certain films may claim to be progressive, their methods of representation are conservative in their support of the protagonist's felt identity (i.e. maintaining their assigned gender is the correct one). On the other hand, depicting transgender and intersex communities to which the protagonist can belong (such as in $X X Y$ and 52 Tuesdays) can encourage the spectator to accept the protagonist's felt identity.

In the last chapter, "Space Invaders," I examine and critique trans and intersex protagonists' relationship to the family home. Drawing upon Sara Ahmed's arguments about comfort and space, the chapter begins by making an argument about the nostalgic idealized symbol of home, and the character's individual relationships to it. This is followed by a description of every individual home of each protagonist, and the way that it sculpts their felt identity. From there, each character is positioned in relation to their family home (and specifically how they regard it). 
All of this analysis develops a critique of the domestic tensions that take place in each site. The chapter is divided in two parts, the first of which I spend analyzing the parental figures (Maura and James) and the way that they control their family homes at the risk of their familial relationships. The second half analyzes the children (Mikael and Alex) in their respective home spaces, which they are both initially trying to escape because they are places where gender is instilled and policed. However, over the course of their respective films, the home space becomes a place of recovery and recuperation when the outside world becomes dangerous. Experiences in the indoors can then be contrasted to the life lived outdoors, and the requirements of gender inherent in each space.

Over the course of three chapters, this thesis examines the methods by which four different audiovisual works fashion trans and intersex protagonists. By closely analyzing different modes that narratively and formally produce trans and intersex characters (undertaken by the self, the camera or the home), the political consequences of the cisgender filmmaker's depiction can be identified. Throughout each of the three chapters, it becomes clear that even though all of these works lay claim to being socially progressive because they feature transgender and intersex protagonists, the way that the cisgender filmmaker directs the viewer to look and listen to the body can also undermine their felt identities. In contemporary media, images of transgender and intersex bodies are becoming increasingly of interest to mainstream audiences while simultaneously, the people who claim these identities are fighting for the most basic human rights. Analyzing the way in which transgender and intersex bodies are represented in the mainstream 
provides an insight into the way in which mass audiences are encouraged to look and listen to these specific marginalized identities. 


\section{Chapter One: The Self Made Trans}

A teenage girl enters her house behind her father, calling out for her mother. She tries the bathroom door but it is locked. On the other side of the bathroom door her mother sits grimly in front of the mirror, razor in hand with a head half shaved and chest tightly concealed in a binder that has been reinforced with duct tape. With increasing irritation, the girl demands that her mother open the door. Eventually her mother relents and reveals himself, disrobed and half-shaven. This is the first glimpse that the audience gets of James, the trans man who gave birth to Billie.

It is within this messy, in-between space that Sophie Hyde's 52 Tuesdays begins. Immediately disrupting any assumption of fixed or stable gender identities, opening with this scene is a far cry from mainstream films with transgendered characters of the past. Trans activist and author Julia Serano argues that traditionally, mainstream trans characters can be categorized between one of two main tropes, "pathetic" or "deceiver" figures (36). In the first category, characters are determined to be "pathetic" based on their inability to successfully be read as their felt gender, while in the second they are deemed a sexual threat to cisgender characters because they "pass" all too well. They are a threat because they wield their sexuality as a weapon against the cisgender characters (Serano 36). These two cinematic tropes can be characterized by the audience's reaction to them; either the audience always knows that the character's assigned gender or they never do until the moment of the grand (read: horrific) reveal. Hyde's protagonist works to deconstruct this cinematic tradition in numerous ways. James is neither "deceitful" (like Dil (Jaye Davidson) from The Crying Game (1992) nor is he "pathetic" like Bernadette (Terrence Stamp) from Priscilla Queen of the Desert (1994). Another classic 
trans trope that James disrupts is the psychopathic killing machine (such as Buffalo Bill in Jonathan Demme's The Silence of the Lambs) that Judith Halberstam identifies (580). There are no pre-made victims or villains here.

This is also where my work begins; in the grey, ethically ambiguous political implications of the post-2005 (the year YouTube was created) trans screen. I will demonstrate that these trans films, though made through similar means, are ultimately more complex and progressive than their cinematic predecessors because of the influences of other creative means of trans expression (both literary and online that stem from the medical autobiography which has historically been required). This chapter proves that even the renderings of the trans figure that are created by non-trans filmmakers are distinctively more complicated and nuanced than their cinematic predecessors.

These works move away from a unified, cohesive narrative and towards a grassroots chronicling of life as it occurs. Furthermore, these films also focus more on the person behind the gender transition than the transition itself. However these post-2005 works are not without problems as I explore in the next chapter. The aim of this chapter is to explore how the central transgender character is represented, first through the manner in which they assert themselves and later through the interpretation of other directors. I will start by examining what we know of the characters through their own demonstrative actions before examining the various narrative perspectives the films assume. This chapter explores the different ways through which the four different protagonists fashion themselves: through language, demonstration, violence, and surgical intervention. By 
examining these methods individually before contrasting them, the problems and benefits of the cisgender filmmaker creating different avenues of self-expression become clear.

Historically, transitioning people's public narratives (in which they disclose their experiences to a medical authority) have been goal-oriented, for the purpose of access to surgery or hormones. Those who desired hormones or surgery have been routinely placed in the position of having to create a narrative of their own lives in order to gain bodily autonomy, as explained by Jay Prosser in his 1998 book Second Skins (108). This narrative was of course impacted by the power imbalance; in order to persuade a medical authority that they have the right to determine what happens to their own body (either via surgery or hormones), a trans person had to create a concise narrative of their gender experience that was palatable to a cisgender medical power.

As Viviane K. Namaste argues in her book Invisible Lives, this has created an "autobiographical imperative": "Transsexuals may be allowed to speak, but only insofar as they offer their personal autobiographies and only as long as they respond to the questions posed by a non-transsexual interviewer." (46). As Namaste describes, cisgender people have controlled not only when and where trans people speak, but also what they speak about, regardless of how personal it is. As a result of the goal-oriented nature of autobiographies that were forcibly approved or denied by physicians, all trans autobiographies took on a similar structure. In her book The Empire Strikes Back, Sandy Stone addresses the reiteration of certain themes in transgender autobiography:

It took a surprisingly long time- several years - for the researchers to realize that the reason the candidate's behavioural profiles matched [Harry] Benjamin's so well was that the candidates too, had read Benjamin's book, which was passed from hand to hand within the transsexual community, and they were only too happy to provide the behavior that led to acceptance of the surgery (228) 
Stone recounts the lengths that transgender patients had to go to in order to justify to a cisgender authority that they deserved certain medical care. In order to gain access to medical necessities, transgender patients had to alter their autobiographies in such a way so that they would gain the sympathy of what Prosser and Julia Serano term, "a medical gatekeeper" (Prosser 101) (Serano 141). By reading the work of Harry Benjamin, one of the first doctors to diagnose "gender dysphoria," in a patient, they were able to study and rehearse their stories, adapting techniques and narratives so that they would gain access to the required medical care. In his book, Prosser explains the role of the cisgender clinician as being "half priest, half detective" (111). As a result, trans autobiographies have traditionally been contained to identical homogenous structures; storytellers become heroes and the journey to sex reassignment surgery becomes an epic voyage. As Tobias Raun eloquently argues, the effects of this kind of homogeneity are such that, "The potential polyvocalities of lived experience are silenced because the stories that the trans people tell the clinician must mirror or echo the diagnosis, matching the master narrative," (254).

In Second Skins (1998) Prosser discusses the ways in which the literary autobiography has been influenced by the practice of medicalized autobiography. He suggests that in the process of creating these autobiographies, the literary tradition of the trans narrative has been sanitized and oversimplified to better appease a mainstream audience where the reader is presumed to be cisgender. The four works assume a similar position because (as I will argue) their over-explanation of queer terms suggests that they are appealing to a heterosexual, cisgender spectator. Specifically, he discusses the way that trans patients have been forced to become curators of their own autobiographies. 
Heavily influenced by the historical medicalized autobiography, Prosser posits that form and content of trans autobiography frequently operate in tandem: "In transsexual autobiography the split between the "I" of the bios and the "I" of the graph, the past selfwritten and the present self-writing, is heightened by the story of sex change" (102). The separation between the tenses of the self is exaggerated: present self (for example a trans woman "she") talks in the present, describing a past when "she" was male. Additionally, Prosser argues that when the goal was to appease a cisgender clinician:

The clinician's reading thus officially confers and by the same token may defer transsexual subjectivity...As the past's recounting is compelled by the knowledge that the future of one's sex is to be determined by what one has to say for oneself, there has probably never been so much at stake in oral autobiography (108) By being in the position to grant a person access or forbid access to treatment, medical gatekeepers have a tremendous amount of influence over the kind of trans narratives that were created and circulated.

While literary autobiography has a clear influence on the narrative of the contemporary trans film, the lack of visual signifiers intrinsic to its literary form must be accounted for in other, more modern forms of audiovisual media that facilitate trans authorship. The historical context in which Prosser was writing in the late nineties meant that trans representation was reserved primarily to text based forms of communication. Despite the fact that trans artists were producing visual art such as sculptures and paintings, the only mainstream media platform that made trans people visually available was via titillating television shows such as Jerry Springer, where the purpose was to scandalize the viewer by publically outing and shaming the "other." However, in the twenty-first century, where technology and the internet as a source of circulation are more readily available than ever before, there are a multitude of audiovisual mediums 
that trans individuals can use to represent themselves, and elements of these online videos are reflected in contemporary cinema. Thus, it becomes necessary to understand how these technologies have impacted the ways in which trans people create and embody their felt identities.

Focusing on the vlogs (video blogs) kept by transitioning people in the United States, Tobias Raun's dissertation Out Online (2012) explores the impact of trans presences online. However, where Prosser finds that written trans autobiographies streamline trans experiences by eliminating contradictory facts or details, Raun argues that video diaries are a better alternative because they move away from this structure: "The trans self does not emerge or unfold within a clear-cut narrative structure but is in process. It is the telling of one's story as one lives it” (259). Raun details how current visual media platforms such as YouTube enable the creation of trans communities online. He posits that the camera becomes a window, a mirror and a parent for the trans vlogger. Drawing on Lacanian theory, Raun argues at length the capacities of the online camera to double as a mirror for the trans vlogger (224). This becomes compounded when the "mirror" has the capacity to generate responses to the image (via the online community). He even goes so far as to suggest that the online community can function as a supportive parent for the transgender host. Raun argues that the interactive nature of the online diaries provide a much more developed representation of the trans experience: "The vlogs are therefore dilating the purpose and scope of literary autobiographies, offering a multimodal opportunity for documenting, telling and commenting on one's story and bodily/identity changes continually - and to get feedback from others" (Raun 259). Vlogs then render the individual figure more malleable and subject to change than literary 
autobiographies. Representing the trans experience as less cohesive and streamlined (by incorporating details that are counter to, or have nothing to do with the gender transition) means that the figures who are depicted for the spectator are more fully fleshed out, and more human, than their literary counterpart.

Just like Prosser's literary autobiography, so too does Raun's online diary share a connection to medical histories. Raun writes: "Medical transitioning technologies become closely connected to and intertwined with the vlog as a medium" (240). Indeed, even in the historical mainstream cinematic depictions of trans people, there are references to anxieties surrounding the medical discourses about the trans body. One specific example in Boys Don't Cry (1999) is when Brandon confides to his friend Lonny that he wants to marry Lana, and Lonny responds angrily, "Before or after your sex change operation? Before or after you tell her you're a girl?!” These three modes of representation (film, literature, and online videos) are all directly related to medical discourse that has historically demanded transgender autobiographies in exchange for hormonal and surgical access. However, in the four works I examine, there is movement away from medical discourse-approved autobiographies and towards grass roots diaries in which life is chronicled as it occurs. This is a significant step for transgender cinema. References to medical discourses are still present but there is a clear effort to divorce the individual from their medical experience. Transferring focus away from surgical intervention is politically progressive insofar as it encourages the spectator to focus on the person experiencing the transition, not just the transition itself. Now that I have provided an overview of the three different approaches to trans autobiography, as well as the medically mandated history from which they all stem, I will now turn to the audiovisual 
works. By analyzing the different protagonists who each employ different modes of selffashioning, it is possible to identify the influences of the different modes of autobiography.

\section{The Kids Are Not Alright}

While each of the protagonists that I examine employs starkly different techniques to self-fashion, it is Maura (the oldest protagonist I examine) who uses the most historically conventional tactic: her voice. The most direct use of explaining the body has conventionally been located in the voice; more specifically, the dialogue that a character uses to explain their relationship to the body. Transparent's first episode culminates in Maura (the trans protagonist) accidentally revealing her felt identity to her daughter. In the midst of an extramarital lesbian affair, Sarah is shocked when her father, dressed as a woman, interrupts her and her lover. This is the first instance in which Maura "comes out" as transgender to one of her children and it is primarily characterized by the change in her voice and dress. The middle-aged patriarch of a family of three, Maura uses language and costume to assert her felt identity. She has a conversation with each of her children in which she identifies herself as transgender. When she comes out to Sarah, she begins by stiltedly referencing her childhood: "So when I was a kid- ever since I was five, I felt that something- that something was not right." Maura uses language to explain and justify her identity. Prosser accounts for this relationship between a transgender person's body and the telling of their life story, "Narrative is also a kind of second skin: the story the transsexual must weave around the body in order that this body may be 'read'" (101). Maura uses her voice to explain her transgender subjectivity. She starts her speech to Sarah by referencing her childhood ("Since I was five"), creating what Prosser 
would term a "narrative" that refutes the body that is read as male. In this way then, her voice provides the testimony that proves that her body has always misrepresented who she feels herself to be.

Despite the fact that Maura has three children to come out to individually, she only really explains herself once. The exchanges with Josh and Ally are elided over and it is only the initial interaction with Sarah that we actually see. As Tami (Sarah's lover, played by Melora Hardin) and Maura stumble through the awkward exchange of pleasantries, Sarah sits in stunned silence until she finally blurts out, "Dad what are you wearing?!" Maura replies, "So, I have something to tell you...” before sitting on the bed, holding out her hand and beckoning her daughter to come and sit with her. She starts recounting her history until gradually Sarah begins to understand and interrupts once more, asking her to be more direct, "Dad are you saying you're going to start dressing up as a lady all the time?" Maura responds with gentle laughter, "No honey...my whole life I've been dressing up as a man." Maura laughs because her daughter assumes that dressing as a female is a costume, when in fact, she has felt forced to costume herself in her assigned male identity. Wearing a long brown wig, a flowy skirt and layered necklaces, Maura's explanation of her sudden change in appearance works to persuade both her daughter and the viewer to accept her felt identity. She is composed and complete, which is reflected in her confessions to her daughter.

Maura's transition is unique in the way that it is drawn out over a long period of time. She does not come out to all of her children at once, but instead, one at a time, over the course of multiple episodes. While she accidentally outs herself to Sarah in the pilot, her daughter Ali doesn't know until episode four, and her son Josh finds out from his 
sisters in episode five but doesn't actually meet Maura in her felt identity until episode six. And while she depends upon dialogue to express her felt identity, Maura's actual words are obscured in the coming out scenes with her other children. When she does come out to her youngest daughter, Ally is on ecstasy (which is reflected in the camerawork). Most of the scene is taken up not with Maura actually speaking but instead with Ally's inebriated reaction. "You finally make sense to me!...I can finally see you! It's like I've never seen you before!" she exclaims, touching Maura's face and looking deeply into her eyes. Josh only finds out about Maura when his sisters tell him during lunch and his initial reaction is laughter.

Spreading Maura's coming out over multiple episodes in this way, in a variety of situations (not all of which she can control) with many different receptions underscores how serious and how monumental a transition actually is. Additionally, it suggests that transitioning is not a single linear progression in a person's life but instead is composed of many different kinds of small, interconnected movements. For example, right after she comes out to Sarah, Maura promises to tell Josh, but when he appears later that day, she changes her mind at the last minute and emerges dressed as a man. Since she initially asserts her felt identity through clothing, wigs and makeup, which can be donned and cast off, Maura's transition is not the forward progression that Prosser describes in trans autobiographies.

An alternative to the epic story in which she fearlessly inhabits the gender she has always felt inside, Maura's narrative involves a series of small steps toward her felt gender but sometimes (out of fear) away from it. When Josh finds out through his sisters and reacts poorly (i.e. laughs and refuses to believe it) the audience understands why her 
fear of his reaction was so strong in the first place. Josh's bald rejection is counterbalanced by Ally's empathy, which is later revoked. She recounts the intimacy of the coming-out situation with embarrassment to her sister later: "I was like basically trying to make out with Dad!” Ally's initially warm reception of her father coming out gives way to frostier sentiments when she is sober, "His toenails were painted, but...he just painted over the toe skin!" and when they go out for brunch with Maura, "Oh my god- Look at his hair!” The reactions become even less receptive when Maura meets old acquaintances who are unaware of her felt identity. Different reactions from each of her children, and all of the people in her life validate the anxiety Maura feels in the beginning of the series; even the welcoming attitudes can give way to a private hostility. Making Maura's coming out a constant rather than fixed event is a way that Transparent evokes sympathy for her, while also providing a more accurate depiction of many trans people's lived experiences. Her interactions with people (both new and familiar) shows that she is continually engaging with people who don't understand and demand that she explains herself.

The final way in which Maura expresses her felt identity is through apprenticeship and advice from other women (both cis and trans). She continually asks the women around her (her daughters, ex-wife and the trans women in her community) a lot of questions about femininity, specifically around areas of commodified femininity. There is one particular scene in episode four when Maura and her daughters are at the mall and they are approached by a sales-beautician. Maura immediately falls victim to the sales pitch of the beautician and her daughters have to warn her that, should they use the products on her, she will have to buy them. Lured by false promises of beauty and anti- 
wrinkle cream, Maura worriedly turns to the sales agent, "I should buy a great many of these products!" This scene works to emphasize Maura's vulnerability. Appearing very helpless and naïve compared to her cisgender counterpart (she did not learn these things when she was growing up, as other women do), this scene exposes a great paradox in Maura's character; while she is completely in control in some areas, she is powerless in others. The dualism is revealed in these scenes when she depends upon cisgender women to help her.

Maura also solicits advice from her trans peers about their experiences of womanhood. Over the course of her transition, Maura asks intensely intimate questions about her friend Davina's experience. For instance, right after they've met, Maura asks whether or not Davina's family rejected her. Proffering these queries, she walks around Davina's apartment, asking permission before going into the bedroom. Touching everything while she probes her friend for answers, she resembles a child, unable to keep still, seeing and devouring the world for the first time. Compellingly, Maura turns to cisgender women for knowledge about consumer based questions about femininity and she turns to her trans women friends for advice on how to handle the world as a woman (i.e. dealing with sexist and transphobic experiences), as though the two fields are mutually exclusive.

Depicting Maura's evolving gender identity developing alongside her pre-existing familial relationships disrupts previous film conventions of trans representation. She is not a brand new person completely divorced from her old identity like Transamerica (2005), nor is her transition represented as a birth/death divide, as it is in literature (such as Lili Elbe did in the excerpts from her diaries (Ames 30)). Historically, and even in 
contemporary media, the transition marks a turning point of "no return" in which a butterfly emerges symbolically from the chrysalis of a former life and moves on into a different, better life. If anything, Maura seems anxious that her transition does not disrupt her previously established relationships with her family. For example, in Boys Don't Cry (1999), Brandon is a stranger in a new town, forging new relationships in his felt identity, which is partly what draws Lana (his love interest) to him. Maura in Transparent is different in so far as she does not seem to be actively seeking a blank slate with which to explore her felt identity. She is desperate to cause as little friction with her family members as possible, which is why her coming out takes a significant period of time.

Maura's ability to assert herself through language is a mark of both her privileged racial and class statuses as well as her age. A white former university professor who is upper-middle class, Maura still demonstrates vestiges of that privilege when she assumes she has the right to use her voice in any space (which is conspicuously absent in the other transitions I will detail later). Her previously privileged and entitled social status means that Maura is the only character I examine that actively questions and tries to unpack gender. This is different from a film like Tomboy where the main character Mikael uses neither of those elements. His silence can be contrasted nicely to Maura's vocalization of her transgender status. While Maura uses language to counteract the gendered expectations of her family, Mikael uses demonstrations of athleticism to validate his claim to masculinity.

\section{Seen and Not Heard}

In contrast to Maura's self-fashioning, which is located in her ability to vocally assert herself, Mikael in Céline Sciamma's Tomboy fashions his felt identity through 
action. Like Maura, Mikael also uses costume, hair and apprenticeship to assert his felt identity, but he mainly relies on proving his masculinity through physical demonstrations. The first five minutes of the film show a child in an oversized t-shirt and basketball shorts sitting in their father's lap, steering the car and helping move into the new apartment. Hair cut short, the child's name is never used. Ten minutes into the film, when he goes out and meets Lisa (Jeanne Disson), she asks him his name and he replies: "Mikael. My name is Mikael." The film encourages the spectator to privately assume that Mikael is male before revealing in minute fifteen that this character (although appearing very male) was assigned female at birth with the given name Laure. This initial misdirection by the camera means that the audience identifies immediately with Mikael's felt gender over his assigned one. The film is encouraging the spectator to see the "truth" of Mikael's gender identification through dress. The formal support (and subsequent abandonment) of Mikael's felt gender by the film is further explored in chapter two. He deliberately molds his felt identity not through language but through the absence of it.

The self-fashioning of the adolescent image and the blurring of gender calls the chronology of Prosser's trans autobiography into question. Mikael exists in what Prosser terms the "I" and the "me" simultaneously, which obscures Prosser's separation of the two. Prosser argues that the "I" and the "me" of the bio must be separated chronologically in order for it to make sense for the reader (for example, "Even though at one point I was assigned male (me), I am now a woman (I)”). But Mikael disrupts this exercise by moving seamlessly across the gender binary without changing costume. He is in a position of both becoming and stasis because he hides his felt identity from his parents and the adults in his life. However, this is complicated by the ambiguous costume 
that he assumes. As Kadji Amin argues in his critique of Prosser's book, "We might understand the construction of transsexual subjectivity according to an organized, progressivist temporality that joins both continuity and change" (220). Mikael demonstrates this new temporality by embodying both his felt identity and his assigned identity in the same costume. Mikael is introduced to the spectator in male clothing that works to naturalize the male identity that he develops.

Mikael's gender presentation, in which passive silence plays a key role, creates an inversion of the classic trans cinema paradigm. The one truly shocking moment of the film comes when the mother calls out for the "girls" to get out of the bathtub and Mikael stands, giving the camera a full frontal reveal of his crotch. This scene replaces the classic reveal that occurs in so many trans films (a la The Crying Game) which capitalize on the role of the trans figure as “deceiver" (248). Unlike it's predecessor, Tomboy's reveal comes fifteen minutes into the narrative, and Mikael's nakedness is not capitalized on (i.e. shocking the viewer is not the aim). Serano argues that the "deceiver" trans figure is an archetype revealed as trans towards the end of a film, wielding their gender presentation against a cis character as a (conventionally sexualized) weapon: "Deception is the scarlet letter that trannies are made to wear so that everyone else can claim innocence" (248). Rebelling against this theme, the Tomboy spectator is encouraged to see the truth of Mikael's identity in his dress, rather than in his physical body. While the film capitalizes on the shock value of his naked body, in the first eleven minutes of the film Mikael never explicitly denies that he is female. His unassuming silence, working in tandem with his masculine clothes and haircut, hearken back to a classic male stoicism. Where Maura self-fashions through language, Mikael self-fashions through 
demonstration. He studies and rehearses masculine actions (such as playing football or swimming) before performing them in front of others. In the same way that he doesn't verbally deny his assigned gender at the start of the film, he allows his actions to speak for his true self.

Much like Maura in Transparent, Mikael's gaze works as male apprenticeship in Tomboy. However, where Maura feels comfortable asking other women about their experiences in order to better know her felt gender, Mikael remains silent, choosing instead to study the bodies and behaviors of his cisgender male counterparts. When the other boys are out playing soccer, he spends the first day at a distance, watching them. Through a series of close-ups where the boys take off their shirts in the hot sun that are directly attached to Mikael's devouring gaze, we understand that he is learning their gender performances. Back in the bathroom, which acts as a staging arena, he examines his body in front of the mirror. As he scrutinizes his naked form, trying to discern whether or not his body will fit in with the other boys his awareness of his difference is evident. Even though he is a child, Mikael is looking for signs that his body will inevitably betray him. However the bathroom space functions in much the same way as the ballroom in Paris is Burning (1990) as a rehearsal area in which he is safe to demonstrate alternative genders.

As the summer continues, Mikael becomes less able to rely on his actions to prove his maleness, and instead must make conscious adjustments to his appearance to ensure that he continues to be recognized as male. He even enlists his younger sister Jeanne (Malonn Lévana) to help him cut his hair so that it will remain short. When the group makes plans to go swimming, more exposure of the body becomes necessary to 
prove Mikael's manhood. When he takes scissors to a female bathing suit and fashions a packer (an artificial penis) out of modelling clay, Mikael creates a version of the body that fits his felt sex rather than his assigned sex. Much like the earlier scene that accompanied the football playing, the swimsuit and packer are constructed within the safe rehearsal space of the interior. It is only after much practice and modelling that he goes to the lake and swims and wrestles with the other boys. He only takes part in their activities and play when he can be assured that his felt identity will pass examination without question.

Mikael's silence is representative of a history of trans people being silenced either voluntarily or by force. His non-verbal assertions of his felt identity are compelling because they are wholly reliant on the assumptions of other people; he neither confirms nor denies his assigned sex. Initially, the only thing he actually lies about is his name and then gradually everything spirals out of control. Most of what Mikael actually does is not lying, but simply remaining silent and relying on other people's expectations of gender. He depends on the people around him to make assumptions based on his gender presentation, which he then neglects to “correct." Mikael's reliance on other people's assumptions, and the lengths to which he goes in order to assure other people that they have gendered him correctly suggests that even at an early age, children have a nuanced understanding of the mandatory requirements that are inherent in gender presentation. Silence is as important to Mikael's method of self-fashioning in Tomboy as it is for James in 52 Tuesdays, in which the character censors himself in order to further his pursuit of surgical intervention. 


\section{(Silence) Cuts Like A Knife}

Silence has been deeply embedded in the trans community and its root cause can be traced to the medical discourse that has impacted literary, online and cinematic trans stories, either fictional or otherwise (Stone 228). Primarily enforced by physicians, who have the power to either allow or deny access to surgery, transgender patients have eliminated details of their private lives that are not in keeping with the medical definition of gender dysphoria. Self-policing in the presence of a gatekeeper is especially apparent in 52 Tuesdays, where the therapist has a significant impact on James's conduct throughout the film. While he binds his breasts, shaves his head, dresses in male clothes and assumes a male name, James's also self-fashions through his pursuit of sex reassignment surgery.

I argue that this is James's primary mode of self-fashioning because this is what characterizes his introduction in the film. Any scene in which James actually tells his daughter Billie that he is transgender is completely elided, and the scene jumps to her reaction when she's packing a suitcase in order to move to her dad's house. When Billie asks James how long he intends her to live with her father, he is very vague, basing his answer around his plans for surgery: "Top surgery can happen in about nine months, maybe longer. The full effects of testosterone can take years.” Or, as James's brother puts it more succinctly, "Until your mom grows a bit more hair on her chest, she doesn't want you around." The omnipresence of medical discourse (and its ability to allow or prohibit James from the surgery he wants) encourages him to police himself not only in front of his doctor, but also with his family. While he uses verbal cues to assert himself (such as 
telling a colleague over the phone his new name), he justifies his year away from his daughter because of his plans for surgery.

Appearance in 52 Tuesdays is used to invert the conventional paradigm of the "reveal" as it is used in mainstream trans cinema. While this film is purportedly exploring the consequences of a gender transition upon the relationship of a mother and their child, it is not the trans person's appearance that dramatically changes. James's introduction within the film begins when he is already wearing a binder and in the midst of shaving his head. Once he appears as a man in the psychiatrist's office (around the ten minute mark) that is how his appearance remains for the rest of the film. The sole contradiction is the film's depiction of top surgery (in this instance a mastectomy), but even the removal of his breasts does not make a dramatic alteration to his appearance.

Where a vast majority of trans films delight in displaying corporeal contradictions (showing a trans woman's penis for example, as in TransAmerica) 52 Tuesdays takes care not to perpetuate that trope. Billie hurls James's static appearance at him in a moment of high tension: "You look exactly the same! You said you were going to become a man!" In no way does the film construct gender transitioning as a progressive, before-during-after event, where a person on one side of the gender binary emerges looking completely different on the opposite side. James' transition is emphasized as painstaking and very gradual. Perhaps part of the reasoning for this is that Del HerbertJane (the actor who plays James) was actually going through a gender transition at the time of filming. Herbert-Jane's transition and its implications for the film will be a key focus in the next chapter. 
The medical aspects of James's transition and the self-policing that accompany it, lead to mounting tension between mother and daughter. In order to prove to his therapist that he is truly a man, James has to leap into his felt identity, which feels foreign to his daughter (who also associates his transition with how he forced her to move out of the house). At her breaking point, Billie eventually throws a tantrum in the therapist's office and the words she uses mimic James's efforts to conceal discrepancies in their life from the therapist. James responds to all of the therapist's questions with nonspecific answers that things have been going "pretty good." Billie sits silently until the therapist asks her how she's been and she explodes at him:

Yeah- time together's been good. Outside of that- I've been lying to Mom each week about going to Tom's at ten. So that's good. You know- actually I've just been going out with friends...fucking around without anybody knowing where I am. So you know that's- that's really good. And Mom hasn't known about any of this until just now ... that's really fucking good isn't it? And James he's been seeing someone; I think someone from work but I don't know anything about that so you're going to have to ask him if that's been good because I have absolutely no fucking idea. I mean maybe you could tell me?!

Billie's word choice here is significant because she's parroting her mother to the therapist while also revealing the details that have been withheld. When she mentions her mother's romantic interest, the camera shifts momentarily to a close-up of James who, realizing his daughter knows more than he thought, looks away uncomfortably. Everything has to be good in order for James to gain access to the hormones (and later surgery) that he needs. And so he does not share the real trouble he is having with his daughter and her inability to understand his transition with the therapist. James' dedication to maintaining a specific illusion of himself is reflected in his anger when Billie upsets the appointment. He seems more upset about her disruption of the appointment than the revelations she makes during her outburst; "You could have really fucked things up for me in there!" Acting as a 
gatekeeper, the therapist becomes omnipresent in Billie's interactions with her mother. We see James try and make a narrative of his own life in front of his psychiatrist, but Billie disproves it and exposes what he's trying to censor.

Throughout the film, James tries to bridge the emotional distance his daughter feels by sharing information with her. Billie's constant interrogation is an interesting reference to the autobiographical imperative because she clearly feels that she has a proprietary right to all of her mother's experiences. Their relationship opens up and exposes the autobiographical imperative that is outlined by Namaste (46) but also begins to dissolve it. Rather than having a pre-formed body of knowledge, James' transition is something that he tries to share with Billie at every stage, mostly through the online videos he makes. The videos he makes mostly consist of interviews with other transmen, some of whom are high profile like the rapper Katastrophe. Billie watches them, seemingly disinterested, and turns away until an interview starts with a woman saying, "My dad became a woman about fourteen years ago." At this, Billie swings back around and watches the interview intently, trying to glean the experiences of the woman on the screen (who talks about going through a depression after her father's transition). Upon its completion she freezes on the woman's face. While James as the parent is supposed to be the authority (and the person who has all the answers), the limits of his knowledge are exposed by Billie's constant questions about his transition. However when Billie watches the video of the woman whose father transitioned, it becomes apparent that she is less interested in the transition itself than on the impact it will have on her life. Similarly, when James begins to explain how the hormones will affect his secondary sex characteristics, her questions become especially pointed. She asks him about facial hair 
and whether or not she should say something if she sees it on him, etc. Eventually James concedes, "How about, if you see it you just let me know, ok?" While his daughter is growing up, Tobias Raun would suggest that James is "growing sideways" (224). Describing when a trans child begins to grow away from what they have been taught by their cisgender parents, "growing sideways" (coined by Katheryn Bond Stockton in 2009) is when a trans person moves into their felt identity. As Billie grows into her sexuality, James (even as an adult) grows sideways into his felt identity. In effect, he goes through a second puberty at roughly the same rate as his daughter is going through her first one, and in this sense Billie and James act as foils for one another, both using cameras and film as creative outlets.

James's pursuit of surgery at all costs is hindered by a lack of available information and resources. His inability to answer Billie's questions indicates the amount of responsibility that cisgender people routinely place upon transgender people to have confidence regarding the care and maintenance of their bodies. As Serano and others have pointed out, it has historically been and continues to be a necessity for transgender communities to be well read, because their physicians may not have experience or training in treating transgender bodies (Serano 157). By admitting that he doesn't know, James is acknowledging the limits of his knowledge about his own body. Transgender people are not allowed to be ignorant about their medical care, and James' honesty about his own lack of knowledge is refreshing. Namaste's autobiographical imperative also sheds light on the silence which is strategically employed by both James and Mikael; when the world continually demands you to speak about intensely private experiences, sometimes the most powerful weapon is to withhold your voice altogether. 
Much like in Tomboy, 52 Tuesdays robs the audience of the voyeuristic pleasure of seeing a person visually transition by introducing the post-transition body immediately. Again this is a dramatic restructuring of the literary trans autobiography. In these films, the climax does not occur when the person chooses to begin a transition, but after it. This suggests that the transition itself is not the most dramatic part of a trans person's life, but rather the reactions to it. James's complicated relationship with his daughter, which undergoes great strain while he transitions, reveals to the spectator the cost of self-policing when in pursuit of surgical intervention.

\section{Bawdy Talk}

At this point, this chapter has detailed the various ways in which the different trans protagonists express their felt identity and explored the ways in which they selffashion. Through costume, hairstyle, voice, surgery and strategic silence, all of the trans protagonists I have examined make certain choices and adjust their behaviors and appearances in order to express the identity they feel themselves to be. I chose to analyze an intersex film alongside the other three transgender pieces because it provides an alternative representation of the experience of both sex and gender. Where all of the other protagonists seem to move (or at least strive to move) from one side of the heteronormative gender binary to the other, Alex (Inés Efron) takes another stance altogether. Whereas a trans person is born into a body with an assigned gender that they choose to move away from, an intersex person's experience is different. Their body can harbour any number of characteristics that are neither typically male nor female. What becomes fascinating in the examination of films in which they feature is how both intersex and transgender protagonists are forced to choose and occupy only one gender 
by the cisgender people in their lives. This is why it becomes necessary to examine an intersex film alongside these specific trans works: because while the differences in bodies and experiences are all various and different, societal methods of pressuring people to conform are often the same. Alex is an interesting intersex character to focus on because of their conscious resistance to these pressures. This is why, even though in the film everyone genders Alex as female throughout my examination of $X X Y$ I will use the pronoun "they" to respect the position that Alex ultimately chooses (to be neither and both genders).

In contrast to the transgender protagonists who consciously change their bodies in order to represent their felt gender, the intersex character Alex in Lucía Puenzo's $X X Y$ clings to their body as the one true artefact that validates who they feel themselves to be. This is reflected in their self-fashioning which is completely based in the nonverbal. Pale, with shaggy hair that falls just above the shoulder and wearing baggy, dark clothing that effectively disguise any presence of breasts, Alex resembles any other skinny, awkward, non-descript, teenager. $X X Y$ creates a similar situation to Tomboy, where the viewer does not know anything is necessarily amiss until it is revealed diegetically through dialogue. The credits of underwater flora are interspersed with shots of Alex running through the wilderness and then sitting alone, lighting a cigarette.

Similar to Mikael, Alex is characterized by silence surrounding their identity, but Alex occasionally punctures this silence with corporeal outbursts (specifically sexual or violent in nature). Unlike the transgender characters detailed thus far, Alex's subjectivity is firmly fixed in the body they were born into. They cling to their intersex body as a site of truth, and this is reflected in their obsession with the tangible. In their introduction to 
Alvaro (the son of family friends who are visiting their parents played by Martín Prioyansky), Alex begins the conversation by accusing him of masturbating in their house. After secretly watching the family arrive from beneath the floorboards, Alex storms up when he's sitting on the beach and says they knows he's "had a wank" by the look on his face. From the very beginning of the film, Alex is then associated by their crudeness, and their desire to shock other people with candid conversation about bodily functions. Being shocking and profane, Alex explicitly comments on Alvaro's body, directing focus away from their own. Even in this initial dialogue, when Alvaro tries to change the subject, Alex reverts the conversation to masturbation: "We're talking about jerking off, not Uraguay!" Their thought process is constantly on the sexual or the violent, and they bring up either subject very suddenly, in a way that reflects their method of self-fashioning. Even though Alex never uses the word "intersex" or talks about their own bodily history, they are constantly preoccupied by the workings of other people's bodies. This goes beyond the natural curiosity of adolescence and into the critical. Alex's corporeal outbursts indicate to the audience that they are working through gender, if only by intensely focusing on the functions of different bodies.

Alex's propensity to talk about the explicit is not limited to referencing the sexual; it also extends into violence. From the moment that he arrives in the house, there is a tension between Alex and Ramiro (played by Germán Palacios, Alvaro's father) who is a cosmetic surgeon. Ramiro represents the threat of surgery and Alex is immediately confrontational around him. When they talk to Alvaro about his father Ramiro they refer to him as "a butcher." This foreshadows a later scene with Ramiro when they talk in the kitchen and he is cutting meat. Locking eyes with him, Alex takes one of the pieces and 
provocatively bites into it. Operating as a comment on his position as a cosmetic surgeon and also working to suggest that he has malicious intentions, this scene sticks out as one of symbolic aggression.

Along a similar vein, when Alvaro sketches the beetle on the beach because it is "a rare species" Alex crushes it under their thumb saying, "What do you know about the species in my house?!" Especially sensitive and reactive to Alvaro's chronicle of a rare bug, it would seem that even Alex themselves are inclined to identify with an endangered subjectivity. Their intersex body means that Alex is highly sensitive to things that are considered rare or unique. Saving the bug from Alvaro's dissecting gaze, Alex uses violence to assert an independent stand; they would rather kill the insect than allow it to be dissected and preserved through art. Not dissimilar to the stand that they take throughout the rest of the movie, Alex's actions are defiant and rebellious. They conduct themselves so to protect their own body from harm, be it social or physical, away from prying eyes and violent actions. Alex's sensitivity and defensiveness of their body further develops the close relationship they have with it. They are not afraid to take physical action (be it sexual or aggressive) in order to preserve their own bodily autonomy.

Disrupting Laura Mulvey’s famous analysis of the male gaze (Mulvey 1989 837), Alex always has command over what is seen or unseen and thus is not objectified. Inés Efron, the actress who plays Alex, is not intersex, which limits what Puenzo is able to show of her naked body. However, this limitation also cloaks the character's intersex status in an aura of mystery and denies the spectators the claim to visual epistemologies around their body. Indeed, Alvaro is never the one who fixates on Alex's body; it is always Alex that reduces themselves to their body. "What do you regret the most?" Alex 
demands, "not seeing me again or not having seen it?" before they expose themselves to Alvaro on the beach by the ferry terminal. Once again the revelation is made to another character but not to the audience itself. Puenzo is playing on the power of suggestion here. It is not the genitalia itself that holds the power but merely the idea of it. Taunting the viewer with the forbidden unseen operates self-reflexively, making the viewer yearn to see and judge. By not showing the physical body that Alex clings to, Puenzo leaves the spectator in an uncomfortable position, ultimately demanding that they ignore thoughts of sex and accept Alex's self-fashioning, allowing them to be, as they wish to be, neither and both genders.

While Alex's experience and physical expression of gender remains static throughout the film, tension arises because they have to fight to remain that way. Their self-fashioning is chiefly located in their desire to rebel against the traditional system of the gender binary. Much like the transgender characters previously referenced, there is some evidence that Alex is aware of gender apprenticeship (such as when they watch their female companion in the shower), but unlike the trans characters, Alex rebels against it. Additionally, where transgender characters such as Maura and James verbally locate themselves from the beginning of their respective works as belonging on one side of the binary or another, the first time Alex really expresses their gender identity comes at the very end of the film. When Kraken (Ricardo Darín, Alex's father) is promising to look after them until they are able "to choose what you want," Alex looks at him for a long moment before asking, "What if there isn't a decision to make?" This is the first instance where Alex vocally refuses to accept a gender label. Their actions speak for them within the duration of the film, but voice is something that they have to grow into. 
Alex coming into the command of their own voice is the most significant turning point throughout the entire film. They are finally in the position not only to make a decision for themselves, but to enforce that decision. In coming into their own voice and defending their own subjectivity, Alex reaches by the end of $X X Y$ a similar place to where James and Maura begin in their films. In effect, Alex moves from teenage corporeal outbursts before arriving at a place where they can coherently voice their own identity at the end of the film.

\section{Conclusion}

This chapter has outlined the artistic streams that have influenced the four screen works under examination (cinematic, literary, and online, all of which have been impacted by medical autobiography). Beyond that I have explored the methods of selffashioning each trans protagonist has undertaken: verbally, demonstration, pursuit of surgery, and, lastly, through violent outbursts. I have detailed the creative outlets through which each character develops, as well as the various methods of gender apprenticeship that are evident in every film that I examine. Of the many different modes of selfrepresentation, one aspect that has significance (either through its strategic use or disuse) is the presence of the voice and the individual's ability to vocally advocate for themselves. In the next chapter, I will explore the various lenses that the works themselves adopt, as well as the ways that the medium itself either supports or betrays the felt identity of the trans and intersexed characters. 


\section{Chapter Two: (Re)envisioning The Trans Body}

From cross-dresser films such as Some Like It Hot (1959) to transgender films such as Priscilla Queen of the Desert (1994), mainstream cinema has always insured that the spectator can be certain of the assigned gender of the protagonist. In these films, characters might dress up and become what cinema scholar Chris Straayer terms "temporary transvestites" (43), but there is never any danger of real gender ambiguity. The camera always directs the spectator where and how to look and listen, making sure that there is never any true doubt as to a character's gender. Accordingly, what the character believes to be true of themselves (or what they are trying to persuade others) has routinely been eliminated in film. In this chapter, I compare the formal strategies of traditional, mainstream cross-dressing films to the techniques used in the four audiovisual works I study. Certain works favour the protagonists' assigned genders over their felt gender, while others depict the felt genders as truly authentic.

Julia Serano calls these transwomen "pathetic" representations insofar as they are ineffectual in their gender presentation: the audience never really believes these are "real" women or men (36). In her book, Serano uses the example of Bernadette (Terence Stamp) in Priscilla and Roberta (John Lithgow) in The World According to Garp (1982), who feature stubble and Adam's apples. She argues that while we as the audience see that this person believes themselves to be a woman, their body ensures that we never believe their felt identity; the spectator does not read this person as an authentic woman. The camera shows the entire body at once, and in doing so emphasizes the contradictions of gender that appear within it- for example, focusing on facial hair on a female identified person. 
In her chapter, "Sexual Disguise and Cinema," about cross-dressing films, Annette Kuhn makes the argument that by showing (and even focusing on) the elements of the body that do not cohere to the protagonists' disguised identity, the camera turns the audience's attention from the subjectivity to the body as a site of truth (57). Focusing on the inconsistencies of gendered physical appearance ensures that the audience never invests in (or believes) the new cross-dressed identity. So while the audience may sympathize with or pity the central character, they never truly invest in their subjectivity. Annette Kuhn argues that in Western society, a valued subjectivity is a gendered subjectivity (52). As such, how the audience interprets a character's gender directly correlates to how they understand the character in general.

Cross-dressing films routinely contrast "authentic" gender expression with the "inauthentic." That is to say, comedic films in the cross-dressing and temporary transvestite genres contrast the men disguised as women with the cisgender, "natural" women. Kuhn goes on to argue that in conventional cross-dressing films, cisgender women (such as Sugar in Some Like It Hot) are presented in close up with soft lighting, enhancing their femininity. Reminding the spectator what a "real" woman looks like projects the illusion that cisgender women exist in a perpetual, natural state of "to-belooked-at-ness" (Kuhn 72) where they are constantly sexually desirable. In contrast, the women who are really men in disguise are never objectified in the same way. While the audience is encouraged to see them as a spectacle, they are never seen as sexually desirable when in disguise. In this chapter I will argue that some contemporary international screen works that center transgender and intersex characters follow in a similar vein: they contrast "inauthentic" trans and intersex gender presentations with 
"natural" cisgender gender presentations. While all of these works might initially appear politically progressive because of their content, their formal structure can reveal an alignment with their protagonist's assigned (rather than felt) gender.

Cross-dressing films give the spectator a certain amount of assurance that they can "read" bodies correctly, unlike the diegetic characters in the film. As Annette Kuhn argues, “'True' gender is repeatedly made visible to the spectator, while the ignorance of the characters within the diegetic world - because unlike the spectator they are not in a position to see the truth - is constantly emphasized" (65). Kuhn's arguments strongly support visual epistemologies that mainstream audiences are trained to recognize; that is, spectators are conditioned to believe that bodies are sites of truth that may either be "read" correctly or incorrectly. Or as film scholars Chris Straayer argues in her book Deviant Eyes, Deviant Bodies: Sexual Re-orientations in Film and Video, "Temporary transvestite films generally present the futility of a character's desire to maintain the disguise indefinitely" (50). The spectator knows, just by looking, what the character's "true" gender is, which indicates that their foray into cross-dressing cannot and will not last forever. As Straayer conveys, within the diegetic worlds of cross-dressing films, it is made very clear that this disguise will only last for so long, before all genders are restored to their right, natural costumes.

Cross-dressing films have historically been so popular with mainstream audiences, they can be useful in understanding the trans film's relationship with the viewer. As both Kuhn and Straayer demonstrate, cross-dressing films create skeptical viewers who believe that they have the power to accurately see and hear a character's true gender (Kuhn 62, Straayer 47). This sets up an uncomfortable precedent for 
watching contemporary trans films, when the viewer has been routinely taught and reassured that, with scrutiny, "true" gender is something that can be decoded and resolved. It is necessary to understand how mainstream cross-dressing cinema has historically positioned the audience so that we might turn to transgender and intersex audiovisual works with a keen understanding of how they may be impacted by (or even succumb to) the same tropes.

One way in which inconsistencies of gender can be highlighted is through the camera's capturing of the body as a whole, interconnected piece. Serano's example of the Adam's apples and makeup on trans women is a key example of this. By showing their bodies fully as a series of interconnected parts that each give conflicting messages, the film sides with the assigned gender. Focusing on the inconsistencies of gender presentation (that both trans and cis gender people struggle with daily) is a significant movement away from the bodily fragmentation that Laura Horak argues occurs in the YouTube videos that were referenced in the last chapter. Having control of the technology means that trans vloggers can use close ups, voice, and other formal strategies to focus on the details of the body that are in keeping with their felt identity. As Horak argues, this works to "draw attention to the aspects of the body that reflect the felt gender and away from the aspects that don't' (577).

In Out Online, Tobias Raun further details how representation can be sculpted not solely by content but also by form. In contrast to the way in which the camera in the cross-dressing film obsessively details the inconsistencies in appearance, the YouTube trans vlogger methodically tracks all the changes that make the body match the felt gender. However, where the cross-dressing film ends with the correct characters being 
restored to their assigned gender, Raun argues that vlogs are more open and progressive: "The vlog is an important part of a process of self-invention, serving as a testing ground for, experimentations with, and manifestations of (new) identities" (239). Trans vloggers forge their own subjectivity by concentrating the camera on the facets of their body that match their felt identity. In doing so they are able to persuade the viewer not only diegetically but formally that their gender experience is authentic.

Having examined the ways that gender is constructed as "true" in both trans films and vlogs, I will now locate the cinematic techniques of the four media works that I am examining between two opposing poles. While each work centres on a transgender or intersex character, each piece shows a different amount of investment into the authenticity of each gender identity. First, I will delve into Sophie Hyde's 52 Tuesdays because it is the best example of a film siding with the protagonist's felt gender. From there, I will explore the techniques of both $X X Y$ and Tomboy, which fall somewhere in the middle, before showing how Transparent, despite the accolades it has received for being progressive, keeps the spectator firmly rooted in the protagonist's assigned gender.

\section{Transffirmative Action}

52 Tuesdays is a good example of both narrative and form working to support the felt gender of the protagonist. The story is supported by the grassroots documentary style of filmmaking that is manifested to support James's felt gender, making the audience believe every step of the way that he is a man. With an emphasis on chronological consistency, 52 Tuesdays was shot over the course of a years' worth of Tuesdays, the scripts being written only a week before filming. During this period Del Herbert-Jane, the actor playing the character of James, was personally undergoing a gender transition that 
very much sculpted the progression of his character. Indeed, Herbert-Jane's bodily rejection of testosterone was an unexpected turn of events to which Hyde and her team had to adapt. Much of the appeal around the film centers on the premise that HerbertJane's transition in real time gives the spectator an opportunity to witness a "real" transition within the framework of a narrative fiction film.

The form in 52 Tuesdays lends authority and credibility to the content. References to the non-diegetic world, through the insertion of global current events and references to real people suggests that Hyde is seeking to contextualize her characters within a broader international discourse on gender. Integrating news footage within the fictional world of the film is another way in which the film strives to demonstrate its authority over the subject matter. By structuring the events in-between the precise intertitles that feature exact dates, this film feels less like a fictional narrative and more like a video-diary. All of these non-fiction elements that are so prominently featured in the film lend support for James' felt identity.

James is not made into a romantic, lonely figure nor is he represented as a martyred victim as Brandon Teena is in Boys Don't Cry or Lili in The Danish Girl where the protagonist exists in a different time period than the spectator and dies tragically. The grassroots, documentary structure that is supported through the formal elements all privilege his felt identity, characterizing James as a productive member of a community that exists in the present. If these exact dates took place, within the broader content of these specific world events, then presumably something like what happens in the narrative really occurred in life. Referencing the broader world also blurs the borders 
between the real and constructed and suggests that the film seeks to eliminate the finite boundaries of the film and make its characters multi-dimensional to the audience.

Further, the film's documentary-like structure positions the spectator as a voyeur who is gaining secret access to a real familial experience. Events occur sporadically and without warning. There is no swelling music or long, moments of tension across the dinner table. One moment that encompasses this theme of real events happening in real time occurs in the middle of an argument. Furious because James has taken away her video camera, Billie punches him in the chest in a moment of rage. Still recovering from a double mastectomy, both James and the spectator physically recoil. After sitting through the arduous process he has undergone both at the hospital and at home, the viewer has experienced recovery with James every step of the way. Tuesday after Tuesday the camera has stayed with him in his most private moments post-surgery, and thus the spectator understands how fresh his wounds still are. As a result, his pain is visceral, and so is Billie's subsequent feeling of abandonment. Her rejection of his transition is symbolized by punching his newly sutured chest. The power of the scene comes from the spectator not only feeling James's physical pain but his emotional anguish as well. Working in tandem, the spectator is left as breathless as James himself, feeling the scene from both sides.

The film represents James's masculinity in ways that are sometimes progressive and sometimes reductive. As Kuhn writes, "In ideology gender identity is not merely absolute: it also lies at the very heart of human subjectivity...the human being is a gendered subject" (52). Speaking in Kuhnian terms, the film compromises the safety of James's subjective position when his body rejects the testosterone and he must occupy a 
more fluid, destabilized gender position. Demonstrating James as having a plurality of masculine positions to choose from is one of the ways in which the film supports his felt gender; his masculinity is defined by his personality rather than his physicality. One day James looks exceedingly masculine, the next he is depressed and the spectator can identify the outline of his breasts (like in the scenes where he learns he must give up testosterone). There is even some gesturing to him menstruating when he goes off hormones, but it only happens through his dialogue when he chooses to disclose it. Menstruating may be a part of his experience but in the film it makes him no less of a man. His physical appearance is not the base of James' gender transition, which is reflected in the way that the images of his body are consistent throughout the film. Instead, the focus of the film's portrayal lies on James' personal vision of masculinity as he strives to embody and realize his own masculine ideals. By presenting multiple masculine possibilities for James to inhabit, the film not only supports his felt gender but liberates him from a heteronormative, binary transition.

52 Tuesdays blurs the line between fiction and documentary through the integration of "talking head" clips. There are multiple instance where Billie breaks the fourth wall and directly addresses the spectator under the premise of talking to her video camera. She may be reaching outside the film, or her messages might be intended for her friend Jasmin (Imogen Archer). Either way, the use of talking heads establishes a direct line of communication between the film and the viewer. Talking heads are also yet another homage to the documentary style that 52 Tuesdays mimics in so many ways. Similarly, James too has certain talking head sequences, but they are explicitly made for 
Billie, and the spectator sees her watching them (something we don't see with the video for Jasmine).

James's videos fall into one of two categories: educational or communicative. He makes them to stay in touch with Billie when he goes to San Francisco, and to keep her up to date on the day-to-day progress of his transition. However, there is the insinuation that parts of his videos are censored by the time Billie sees them, and that she is not privy to all of the information. For example, there is one scene that takes place with the camera focusing on James's computer when Lisa (his lover, played by Danica Moors) stumbles into the frame. In the midst of documenting his bodily changes (keeping track of his own "hormone time" [Horak 579]), James immediately stops. "Now I'm going to have to start again...I show that to my kid remember!" he says, gesturing towards the laptop. This scene implies that Billie doesn't know about Lisa, and that James intends to keep it that way. His systematic elimination of certain information also demonstrates a forethought that Billie does not seem to possess. He keeps things out of his videos because he does not want Billie to know certain, private information about his personal life, whereas Billie puts anything and everything she is feeling into her videos.

52 Tuesdays also supports James's felt gender by referencing a larger trans community to which he belongs. During his trip to San Francisco, he sends Billie multiple video messages, in which he interviews other trans men about their experiences, about their transitions and about their relationships with their children. This is a departure from traditional, mainstream, trans narratives because the trans character is not singled out or alone. His subjectivity is given more authority and recognition because he is displayed as being one of a group of people who occupy a shared identity. Further, these 
references to other trans men are significant because they seem to be from the real world (yet another instance in which the line between documentary and fiction is blurred). The significance of this haziness between fiction and nonfiction means that the spectator is never certain what is fictional. The film works so hard to persuade the spectator that certain things are real (dates, the transition, etc.) that the line separating fictional narrative from documentary becomes increasingly tenuous. In effect, the amount of work that goes into pointing out what elements are "true" eclipses the fiction and persuades the spectator that all of the events really occurred. Talking head interviews are particularly significant because they demonstrate James' relationship to a broader trans community. In certain sense, the interview clips that he sends Billie function as confessions of his own experience.

A key method of supporting the protagonist's felt identity in both 52 Tuesdays and Transparent is the presence of trans communities. The emphasis is on dispelling the isolation that is so prevalent in films like The Crying Game (1992), Boys Don't Cry (1999), Transamerica (2005), Albert Nobbs (2011), Dallas Buyers Club (2013), About Ray (2015), The Danish Girl (2015), XXY (2007) and Tomboy (2011), in which the respective protagonists are the only other sexed or gendered characters. In contrast, both 52 Tuesdays and Transparent show the dispersion of information and the creation of a community happening freely via the internet, to any and all who want it.

Legitimizing James's creative forms of self-expression is another way in which the film stands behind his felt identity rather than his assigned one. Formally, the film equates the artistic experiences of both mother and child, of trans and cis people, by giving them both private time on screen and making them appear equally valid. One of 
the most politically progressive elements of 52 Tuesdays is how much individual screen time James is allotted. While the film is told predominately through Billie's perspective, about a third of the film is devoted to showing James on his own. At first glance, this might seem less progressive than it actually is, since the film centers around the events of his transition. However, in showing James living his life without Billie (i.e. traveling, spending time with his girlfriend, etc.) his character is more fully fleshed out and developed than the typical trans character in mainstream cinema. Following only James, the camera captures him working, making business calls and referencing his new name, in scenes that Billie does not seem privy to.

All of these tiny details, which might be insignificant in another, non-trans film, characterize James as a fully functional adult. His character is not solely characterized by his association with a cisgender person (though the film does focus on relationships). Billie is not James' anchor to the world; he has his own life happening in the background. As minimal as they are, these references to James operating on many levels of society (not just as a parent) all show the film siding with his felt identity by demonstrating that his felt identity is functional in all circumstances. In contrast, Transparent's Maura has her felt identity tested over and over again, only to have it continually fail in different spaces, as I will show later in this chapter.

\section{Playing the Boy}

While 52 Tuesdays relies on the documentary format and a gender nonconforming actor to ensure that James's male identity is read credibly, Tomboy relies on costume and physical performances of masculinity to support Mikael's felt identity. Mikael's efforts to preserve his male presentation in Tomboy are unusual within 
mainstream trans cinema in that his appearance is consistently masculine throughout the film. The viewer is encouraged to empathize with Mikael because he is staying loyal to the gender that the cisgendered viewer assigns him in the first place. As described in the first chapter, from the beginning the film supports the viewer in their initial assumptions that this child is a boy. Most of the film's narrative takes place from Mikael's point of view and its formal elements present his masculine gender identity seriously. However, this approach is undone at the end of the film. The political implications of this kind of about-face regarding prepubescent gender dysphoria are substantial. Even the very title suggests that this time in his life is more of a phase rather than foreshadowing his lifelong gender identity.

The majority of the formal elements in Tomboy work not only to support Mikael's felt gender but also to convey his thought process. In particular, the camerawork makes up for the dearth of Mikael's dialogue and the film is shot all on Mikael's eye line (showing what he sees as he sees it). By keeping the camera low, Sciamma gives credence and credibility to the struggles that Mikael is facing, encouraging the audience to take his experiences more seriously. In a variety of ways the film is shot to lend meaning to his experiences, rather than dismissing them as routine childhood mishaps. Mikael speaks so little that this obsessive tracking of his eye line allows the viewer see what he sees, and thus provides an entry point into his emotions.

Yet the film also occasionally uses scale in order to foster sympathy for Mikael by emphasizing his solitary, tiny figure. Specific scenes use enormous scale to wrench the viewer out of the intimacy with Mikael that they have grown accustomed to throughout the duration of the film. This is most effectively used in the scenes immediately after his 
mother forces him to reveal his assigned identity to the neighbours in their apartment complex. His friends have just forced him to expose his genitals to Lisa, the girl he is in love with. He is abandoned and at his most vulnerable, cowering beneath the trees, humiliated. However the spectator does not know this from the exclusive position of his eye line. Instead, the camera jumps to an extreme wide shot, showing a little boy by himself crying. Forbidding the audience to intrude on this moment of private pain, Sciamma forces some modicum of respect and decorum into the scene.

After a film that has consistently focused on Mikael's most minute expressions, the audience is abandoned to their own thoughts about the narrative. This distance works to encourage empathy towards Mikael. We see the events through his eyes for the duration of the film and then we are left alone, a moment of separation in order to consider the magnitude of the events that have transpired. Adult eyes can understand the future ramifications that are in store for this child. The intense humiliation of this scene reduces Mikael to his most vulnerable and we see it only from a distance. This works to not only make the spectator understand how physically small and young Mikael is, but also to give him privacy to grieve.

The spectator's support for Mikael's felt gender is developed in the contrast between his gender experience and that of his younger sister Jeanne. Six years old and presented as very traditionally feminine, Jeanne wears tutus and fairy wings; she tries on makeup and loves to sing and dance. When they play together in the bathtub, Mikael interviews her and she pretends to be a famous singer. She is so conventionally feminine that her character begins to function as a commentary on the impact of media on young children and gender roles. When she's in the bathtub alone, she sings a sexually explicit 
pop song as she plays by herself. So while Mikael has to consciously work against the gender roles that he is assigned, the film presents Jeanne as the cisgendered child who is unconsciously indoctrinated into predetermined sexuality and gender presentation. Both of these representations seem to align the film with the privileging of felt gender over the assigned gender. However, this work is undone by the narrative and formal backtracking that takes place at the end of the film.

All of Mikael's efforts described in the previous chapter, such as changing his swimming suit and creating a packer out of plasticine, work to support his male identification. For the majority of the film, the camera works to support his felt identity by showing his perspective. However, even though he is successful for almost an entire summer, Mikael's efforts are ultimately in vain. Despite the fact that most of the film is shot at his eye level, and at times the camera even takes his perspective, the ending of the film presents Mikael's assigned gender as the preferred one.

When he is outed to his mother and she takes him on the aforementioned exposure journey through the apartment, he is left to pick up the pieces. He is humiliated, shoved against a tree while his former friends mock him and make Lisa look down his pants to confirm his mis-gendering. Yet somehow, through all of this humiliation, the most disturbing moment in the film is the final minute, when Mikael voluntarily reintroduces himself to Lisa as "Laure" and smiles. Uplifting non-diegetic electronic music suggests that this is a positive or hopeful moment of change. The music is sweet and nostalgic, keeping with the whimsical childlike feel of the film. The music reassures the spectator that ceding to his assigned gender is a triumph. 
The end of the film completely betrays the gravity with which the rest of the film has treated Mikael's felt gender. Even though throughout the film he has chafed against the conventional femininity represented by his sister Jeanne, he capitulates to societally regulated gender roles. The lesson that can be gleaned from the film seems to be that it is easier for everyone if the trans person concedes to societal restrictions around gender than to fight for an individual identity. All of the work that has constructed Mikael's experience of gender with gravity and seriousness is eroded by the final moments in which he is forced to live by his assigned name. It is this last-minute revocation of Mikael's autonomy that completely circumvents Tomboy's cinematic structure, making it clear to the viewer that his assigned identity is much more important than the one by which he identifies.

\section{The Cutting Room Floor}

While Mikael's assigned identity is unexpectedly forced on the viewer at the last moment, the structure of $X X Y$ is more progressive if only because it depicts Alex slowly gaining the confidence to assert their bodily autonomy. Unlike Tomboy, where Mikael's parents don't realize he is slowly modifying his appearance, in $X X Y$, Alex's parents are initially reluctant to let them stop taking the hormones that make them present as female (which modifies their body). While this film does not lie on the same spectrum as the trans works I have referenced thus far, just as Transparent, 52 Tuesdays and Tomboy take positions on their protagonists' genders, so too does $X X Y$ take a position on Alex's sex.

The formal elements of the film initially take a distinctly different position on Alex's gender and sex than Alex does. In the beginning of the film, Alex is introduced as a girl and their intersex history is not even referenced until halfway into the narrative. 
When Alex is introduced to Alvaro's family, all that Suli (Alex's mother) says is, "this is Alex" rather than adding a modifier (i.e. "this is my daughter, Alex"). However, because the dialogue is all in Spanish, many words are inherently gendered. With this in mind, it is possible that Alex's parents may be gendering them in ways that are not translatable in English.

Although, there are several ominous moments of foreshadowing before Alex being intersex is made explicit (such as when Alvaro sees Ramiro reading Alex's medical file and a book entitled The Origins of the Sexes) Alex's gender is more or less stable. All of the pronouns used to describe Alex are "she" and "her," which do not change even at the end of the film once they have asserted their desire to be both/neither. Indeed, because the entire film passes without any visible change in Alex's body, the change that takes place is entirely a matter of subjectivity. Thus, the way the film actually approaches Alex's felt sex is pivotal to the way their subjectivity is understood.

Alex is not advocating for their "felt" identity over their "assigned" gender. Instead, they are fighting for their right to go off hormones, and live in a sex that is non binary and different than the sex that their parents (under the doctor's recommendation) established would be most appropriate (female). In essence, both trans and intersex protagonists are fighting against the gender that was assigned to them, but where the trans protagonists are fighting to be stabilized in a different position, Alex is fighting to affirm their ambiguous bodily sex.

$X X Y$ falls victim to many of the same problems as Tomboy. For example, the title $X X Y$ is misleading. Having $\mathrm{XXY}$ chromosomes instead of $\mathrm{XX}$ or $\mathrm{XY}$, also called Klinefelter Syndrome (Genetics Home Research, 1) is only one of many types of 
intersexuality and it is not the condition that Alex appears to have. Indeed, Alex's biological intersex condition is only referenced in the broadest terms. However, it is clear that Alex has been living as female, has ambiguous external genitalia and (at least in the beginning) is taking prescribed hormones to keep their body appearing female. But the choice of title must be examined because of all the possible inferences a spectator can draw from it. The insinuation is that Alex is medically unique and a genetic anomaly (even though Klinefelter's Syndrome is not rare, and occurs in one out of five hundred newborn males [Genetics Home Research, 1]). Further, the title locates the source of all difference to the level of the body, which (on a structural level) suggests some kind of scientific objectivity. However, the invocation of scientific authority is misguided when there is never any actual mention of Alex's condition by name and there is very limited reference to actual medical intervention.

Despite the misleading title, $X X Y$ ultimately ends with Alex enforcing their own bodily autonomy (which is a significant change from the progression of Tomboy). As Alex asserts their right to occupy a non-binary gender position, Kraken and Suli eventually relent and become understanding and supportive, dispensing with Ramiro, (the cosmetic surgeon), and all of the surgical intervention he symbolizes. So while there are formal elements that side with the assigned sex, after some struggle, the film sides with Alex in occupying their felt sex.

By emphasizing the past and the way Alex looked at birth (through dialogue) the film anchors the spectator to Alex's own wishes, suggesting that the intersex body is the one they should occupy. Both Kraken and Suli are constantly describing to the other characters the experience of seeing Alex's infant intersex body. However while they 
remember Alex as a toddler in detail, Alex as a teenager is still somewhat of a mystery. Suli and Kraken are the typical parents of a teenager, forever being surprised by Alex's choices. When Suli tells Kraken that Alex has stopped taking hormones, he is visibly shocked. We later learn that they have gone off hormones for the past several weeks (so the effects are beginning to occur). The audience learns these revelations when Alex's quest for bodily autonomy is already in motion, rather than seeing them make the choice. In one scene as Alex wakes up in the morning, they balance the hormone pill on their chest between their breasts before casually flicking it away. The striking image of the pill positioned between the secondary sex characteristics it causes reinforces the choice that is at hand. $X X Y$ is constantly referencing the hormones that Alex has to take and the potential consequences if they choose not to. By reinforcing the choice at hand but making it invisible, the film seems to implicitly condone Alex's choice of going off hormones and returning to their felt sex.

When Suli takes Erika and Ramiro to the beach where Alex was conceived, Suli recalls how at the time she was afraid of the people passing by noticing them. She then ponders aloud, "How ridiculous it is to care what people think" when remembering how people were continually asking whether Alex was a boy or a girl. Strongly invoking the feeling of many parents of intersex children who are afraid of outside reactions (Morland 113), this scene alludes to Suli's conflicted history with her child's intersex status. Cultural critic Iain Morland suggests that parents of intersex children would do better to shame those who try to invade private spaces by looking, rather than accept the gender guilt that is forced upon them (113). All of these events that are remembered but never 
represented (i.e. we hear about them but we do not actually see them happen) keep Alex firmly rooted to their family.

Much like James's San Francisco adventure in 52 Tuesdays, Alex's felt gender is supported through $X X Y$ 's conscious effort to locate them as a part of a larger intersexed community. Unsure whether to support Suli in her quest to ensure Alex's femaleness or Alex's desire to be non-binary, Kraken reaches out to Washington (Cesar Troncoso), an intersex man who owns a gas station, after reading about him in the newspaper. Born intersex but raised as a girl, Washington grew up to realize he identified as male. In their conversation, Kraken wonders if he has made a mistake by allowing Alex to grow into their body and choose their gender. In response, Washington says his earliest memories are of "medical examinations...I thought I was so horrible I had to have five operations before my first birthday." Washington then goes on to say how the surgeries he was subjected to "are not surgery-- they are castration." This dialogue, along with Washington's very presence, indicates the film's stance in siding with Alex in their wishes to occupy a non-binary gender. Or, as Washington suggests, "Making her afraid of her own body is the worst thing you can do to your child." Kraken's interaction with an intersex person other than Alex functions in much the same vein as the San Francisco interviews that James conducts in 52 Tuesdays. By demonstrating that someone with an intersex identity can mature and assume bodily autonomy, function in multiple spaces, with different types of people, the film takes the label of "intersex" from the abstract to the personal. Having an older intersex person in the film who shaped their own identity is suggestive of what Alex might one day be able to do and what they might have (a family and a business). 


\section{The Skin I'm In}

The Transparent series begins in a similar position to where $X X Y$ finishes: with a protagonist who has only recently learned how to assert their voice and express their felt identity. Prosser posits that transgender autobiographies were pitched as epics that heteronormative societies would be able to understand (i.e. a hero's journey) (82-83). Much of Transparent's structure initially suggests that Maura is that same hero; a long suffering woman, tortured by her secret identity who at long last finds the courage to live her truth.

In the previous chapter, I explored some of the positive ways in which the series presents Maura's self-fashioning. In this chapter, I will explore some of the less progressive aspects of the way the series affirms her assigned gender over her felt gender. By surrounding Maura with self-involved cisgender people who constantly overshadow and critique her, as well as using a famous cisgender actor to embody her, the formal elements of the series are entrenched in who Maura was (i.e. her assigned identity) rather than who she wants to be. Firstly, by contextualizing Maura amidst her self-involved, neurotic children, the series places gender transition on the same level: a product of selfinvolvement and neuroses in which the person takes themselves too seriously. The television series does not take into account, nor does it acknowledge for the first few episodes, how difficult the process has been on Maura herself. This is a story in which a transgender person upsets the life of cisgender people merely by existing. Throughout the series, the focus is on the trauma that the cisgender people feel from the discovery, rather than that which is endured by the transitioning person. 
When we examine how the camera treats Maura versus the other members of her family, it becomes increasingly clear that this is not the story of a trans person so much as it is a series that follows a story that is trans-adjacent. The camera does not spend much time with Maura herself but instead sticks closely to the reactions and consequences that her three children experience. One specific example is when Josh finds out about his father's transition. As described in chapter one, he finds out from his sisters, and then goes to confront Maura. Throughout this interaction (which takes place over the course of episode five and six) the camera stays with Josh. We find out through dialogue that Maura assumes that Sarah and Ali told Josh but the actual scene where she finds out is absent. Maura asks Josh, "Did your sisters talk about what's going on with me?" That she phrases it as a question here is telling. Her relaxed posture would suggest that she assumes that her daughters went behind her back and outed her without her knowledge or permission. Whether or not she knows for certain that she has been outed is ambiguous because the camera takes Josh's perspective rather than hers. Even the private time she gets on screen is heavily influenced by her cisgender relationships. Maura may get about a quarter of the screen time overall, but most of that time is spent in flashbacks, when she was inhabiting her assigned identity rather than her felt one.

In addition to a camera that assumes her cisgender children's point of view, the high-profile male actor who embodies her also significantly disrupts reading Maura as an authentic woman. Maura is played by Jeffrey Tambour, a successful actor who gained fame through roles as the patriarch of dysfunctional families in the television series Arrested Development (2003-2013) as well as the 2009 movie The Hangover. Compellingly, Arrested Development is akin to Transparent in story: centering on a 
dysfunctional wealthy family that must learn how to survive once their patriarch (played by Tambour) is arrested for fraud. The implication is that gender transition is equated with a fraud; suggesting that a gender transition is inherently fraudulent or embarrassing in some way. From the beginning, audiences who are familiar with Tambour's career are set up to understand Maura's felt identity as some kind of con. IMDB rates Arrested Development as the $28^{\text {th }}$ greatest television show in all of television history (IMDB 2003) and it was nominated for eighty-five awards. Arrested Development shaped Tambour's entire career. The thematic crossover between Arrested Development and Transparent is startling; a patriarch who (either through crime or transition) causes a situation that brings a significant amount of vulnerability and potential embarrassment to the family.

Tambour's visibility and notoriety to mainstream audiences position him, as the person embodying Maura, as someone more male than female. His celebrity status creates an extra layer of text that the audience must see through in order to reach the character of Maura. His high public profile also is strategically used to position the spectator in the perspective of the children. Tambour is a highly influential male figure who has played almost exclusively father figures in the public eye. Audiences familiar with his work know his standard character to be a traditional family man who partakes in masculine activities (such as fawning over cars in The Hangover). Thus the spectator who is familiar with his work experiences the same cycle of emotions as the rest of his family: doubt and a sense of betrayal. Using a famed male (and very masculine) actor means that the audience is prematurely positioned to question Maura's felt identity.

Where 52 Tuesdays capitalized on the presence of a real (and previously unknown) transitioning person, Transparent markets itself as a show where a much 
beloved fictional patriarch transitions. Part of the show's allure is in watching someone audiences have known for a very long time appear as a woman. Different techniques invite a similar voyeuristic desire in the spectator. But while Hyde's film centers around a non-actor going through a real transition, Transparent's appeal at least in part from stems from titillation; luring the audience to see a well-known, affluent white man in drag. Kuhn argues that in cross-dressing films this is done deliberately (65). Transparent's casting does something similar by using a high profile actor. Thus, from the very beginning, the series is firmly ensconced in Maura's assigned gender rather than that which she feels herself to be.

As for the audiences who perhaps are not familiar with Tambour's professional resume, the costume and makeup still do little to support Maura's embodiment of her felt identity. Throughout the course of the first season, the camera captures her struggling with the various accoutrements of femininity (hair, clothing, makeup, etc.). Viviane $\mathrm{K}$ Namaste argues that the depiction of trans women as obsessed with consumer-based femininity (clothing, makeup, etc.) is an unrealistic depiction of most trans women's experience. In this way, "The arbitrary criterion of physical appearance is...disconnected from the everyday realities of transgendered women" (180). Even at her most feminine, Maura still appears remarkably male. Maura is not portrayed as convincingly female and thus she occupies a position that is in dangerous proximity to the "pathetic," a caricature that Serrano references in her book (36).

However, audiences who are familiar with Tambour's work might take Maura's subjectivity more seriously if his performance as female convinces them. Should the spectator experience a moment in which they truly believe Maura is a woman (despite 
the famous man playing the role), it would be doubly significant for that particular spectator. Yet I would argue that Tambour was not cast despite his fame but because of it. His allure and his position as a famous cisgender actor mean that the viewers following him from one series to another are curious to see what he will look like as a woman. Tambour is so firmly entrenched in his masculinity in the public eye that (along with the unconvincing makeup and wigs) using him as an actor means that the Maura will always be at least slightly obscured by the famous man playing her.

Furthermore, a great deal of the series is spent by people explicitly criticizing and undermining Maura's felt identity. At first, each of the cisgender children in Transparent are averse to interacting with Maura (or at the very least feel alienated and uncomfortable around her). Even if he is not always portrayed sympathetically, Josh's critical approach to Maura's transition opens the door for doubt and disbelief in the spectator. Having a character who means so much to the protagonist be so openly critical of her transition gives the transphobic spectator some reassurance in critiquing her as well.

After Maura comes out to him, Josh's immediate reaction is uncomfortable acceptance, so long "as it's behind closed doors." Afterwards, though, he confides to his sisters that he believes that his father is suffering from early signs of dementia by trying to get attention. He is disturbed when they side with their father: "You guys think it's real?!" He only overcomes his prejudice by spending time with his father, and even then he does not embrace his father's trans status so much as he learns to tolerate it. Even his tolerance comes at a price though; in large part what motivates him to "accept" Maura is access to her bank account. The television series spends far more time watching Josh tailspin out of control (e.g. proposing to his girlfriend, throwing a violent tantrum and 
quitting his job) than it does detailing Maura's transition. But as he and his sisters are eventually forced to spend time with her, they realize that it was the same person they loved all along. A great deal of time is devoted to Josh's suspicion that Maura is crying out for attention and not really transgender, a storyline which is never really resolved within the first season.

The series spends a great deal of time differentiating between trans women and "real" (cisgender) women. This is exemplified by the use of certain language. Learning queer and trans terminology is something that the characters in all of the works that I study seem to struggle with, perhaps as a way of introducing these terms to a presumably cisgender, straight audience. Josh especially struggles with misgendering his father after the transition, constantly referring to Maura as "he" and "him". Similarly, after Maura comes out as transgender, Ali and Sarah privately laugh about how she incorrectly painted her toenails. While perhaps meant to be innocuous, this throwaway line implicitly condemns Maura for failing a gender test. All of this works, as Kuhn argues, to remind the audience what a "real" woman is (72). All of these works assume a cisgender spectator, taking care to explain terms like "high femme" (in episode seven) that most trans and queer viewers would presumably already be aware of.

Sly asides to the audience align the show more with Maura's assigned identity than her felt identity. Dialogue and framing that undermine Maura's felt identity constantly appear within the Transparent series. By surrounding the main protagonist with characters who undermine her felt identity, and constantly comparing cisgender women to trans women the series implies that cisgender women's femininity is somehow more authentic than trans women's. 


\section{Conclusion}

In this chapter, I have explored the formal elements that align these audiovisual works with the protagonists' felt or assigned identities. Different audiovisual works use diverse techniques to persuade or discourage the spectator to believe the characters' felt identity. A methodical examination of the framework of each piece demonstrates how each work occupies a different position on the scale of representing identities. Of the works I focus on, 52 Tuesdays occupies the most politically progressive position and is particularly advanced compared to the Transparent series.

While a work might, at the outset, claim to be politically progressive because of its content, its stylistic elements can prove reactionary in practice. Works that might be regarded as progressive in the mainstream can prove to be remarkably exploitive and troubling. Keeping a cisgender viewer comfortable with their preconceived notions of a dichotomized gender binary does not encourage them to seek out and show empathy towards gender non-conforming individuals. If anything, it does the opposite. 52 Tuesdays is particularly effective because it destabilizes traditional gender practices by fully supporting its trans protagonist both narratively and formally. $X X Y$ ends up being similarly progressive, after a prolonged duration where Alex struggles to find their voice amidst the impending threat of surgery. On the other end of the spectrum, Mikael's felt identity is ultimately silenced in Tomboy, despite most of the film constructing his experience as authentic. Last, by surrounding Maura with self-involved cisgender people who constantly critique her and by casting a famous cisgender actor, the formal aspects of Transparent are more supportive of Maura's assigned identity than her felt gender. 
After demonstrating in the first chapter how trans characters fashion themselves, this chapter explored how each audiovisual works uses camerawork and formal elements to direct the spectator to understand either the protagonist's felt or assigned gender as more authentic. Moving forward into Chapter Three, I will analyze how the protagonist operates within and away from the family home, both as a nostalgic symbol and a literal site. This indicates how the family home also works to fashion the trans and intersex felt identities that these protagonists experience. 


\section{Chapter Three: Space Invaders}

They say you can never go home again. This chapter explores the way certain works represent transgender and intersex protagonists as either desperate to return to, or desperate to escape, the places from which they came. I am specifically interested in the movement towards and away from the family home, and the way that the home functions as a space of both enlightenment and embitterment for trans and intersex characters.

The first chapter of this thesis explored the ways in which transgender and intersex protagonists fashion their felt identities. From there, chapter two detailed how the audiovisual works formally support either the assigned or felt identities of the main characters. In this chapter I will demonstrate the ways in which the family home (both as a symbol and a physical site) can be a space of both possibility and limitation; of liberty and imprisonment.

There are distinct differences between the family homes that each of these protagonists occupy - from a cabin in an Uruguay nature reserve, to a bungalow in Australian suburbia, a crowded French suburban apartment complex or a mansion in Los Angeles. However, by contrasting their unique interactions within their different domestic spaces, similar themes and issues become apparent. In this chapter I will explore both the tangible and intangible elements of each domestic, familial space. All of the trans and intersex characters I study have an idea of home, which at some point comes into conflict with the actual events that occur in the space.

In order to accurately understand the trans and intersex experience of the home, it is first necessary to analyze how comfortable each individual feels there, especially when 
embodying their felt sex or gender. As feminist and postcolonial scholar Sara Ahmed argues, "To be comfortable is to be so at ease with one's environment that it is hard to distinguish where one's body ends and the world begins. One fits, and by fitting, the surfaces of the bodies disappear from view." (148). While Ahmed is referring to public space, this sentiment is a key component of the romanticized ideal of the nuclear family home, an ideal that all of the protagonists I focus on come into contact with at some point. Ahmed argues that the idea of seamlessly fitting into a space means that one does not recognize the process of fitting; it is only those who do not fit that recognize the privilege inherent in belonging to a certain space (157). Indeed, within the nostalgic, idealized vision of the nuclear family home, a similar sentiment is instilled: within a heteronormative family, every individual is entitled to or belongs within the family home.

While the nuclear family home has historically implied a safe space for the individual, this has proven remarkably untrue for trans and genderqueer youth. While statistics on international trans populations are unclear due to lack of documentation, The National Center for Transgender Equality in the United States states that in the America, "more than one in ten have been evicted from their homes, because of their gender identity" ("Housing and Homelessness," 1). While in the heteronormative mainstream consciousness, the family home has been traditionally depicted as a private, sequestered space where one can truly be themselves, while the public space harbours unforeseen risks and judgements, these trans and intersex films dispel this myth. Thus, the spaces in these films that are designated as more or less dangerous differ for each character. This chapter will explore the different delineations of spaces as safe or unsafe for each individual protagonist. 


\section{Family Values}

While each respective screen work takes its own unique perspective on the issues of gender and identity, "the domestic" figures heavily into each of the fictional narratives. Across these four audiovisual works, there is a theme of representing the parent as the overly protective, intervening figure. All of these audiovisual works take up the parentchild bond as a central theme, but it is manifested in different ways. XXY, 52 Tuesdays and Tomboy examine parenting as an immediate, all-encompassing caretaker responsibility. Intervening at a different moment, Transparent captures the transitional point in which the parents are the ones who need to be cared for. That familial relationships are so integral to the transgender narrative in the works I examine is unusual for transgender works. For example, in films like Sabine Bernardi’s Romeos (2011), families are made post-transition, outside of the family home. Biological blood bonds are the priority here.

These works do not deal with protagonists who forge into the world and sculpt their own families, the way prominent scholars and activists such as Susan Stryker have recounted doing (254). Transferring the narrative from public space (where it has been historically located) into the domestic is an important shift in the transgender narrative. All of these audiovisual works frame the family home (and the domestic sphere) as the crux of conflict within the transitioning person's story. Familial bonds both enable and prevent the protagonists from embodying their felt identity, because family members were the ones who implemented the gender that the individual is rejecting and their support (or lack thereof) is pivotal. 
With these domestic ties in mind, the home becomes not only a site of safety but also a place where, from the earliest ages, gender norms and behaviors are instilled and subsequently policed. All of these works feature characters rebelling against gender norms, either as a prepubescent policed within the family home or later as an adult who has control over it. Once the individual embodies their felt identity, occupying their previously established position within the heteronormative family space becomes difficult. As a result, the invisible preconditions and rules of gender that are mandatory components of familial roles are exposed. The conscious or unconscious disciplining of gender is revealed when a person identifies as a gender other than the one that they were assigned at birth. By refusing a predestined role (to be a father, mother, son, or daughter) the trans or intersex character exposes the way that gender plays a pivotal role in the power relations between family members. For example, in Transparent, Maura consciously steps away from her position as the patriarch when she transitions and in doing so, leaves herself open and vulnerable. In the midst of her transition, she is constantly turning to other women for advice on how to be feminine, which changes the power dynamic with her daughters.

In this chapter, I will start by establishing the physical site that embodies the family home of each protagonist. From there I will elucidate the reasons why each character may want to either escape or return to a home. Last, I will analyze how the character functions in the world outside the home, specifically analyzing the ways in which risk is either escalated or decreased when they operate in public. However, because of the different roles of the various protagonists (both James and Maura are parents, while Mikael and Alex are children), this chapter has a split structure. The first 
half will contrast the two parents by examining James and Maura in relation to the families that they helped shape. Comparing the levels of control a transitioning parent may possess reveals the dynamics of power and bodily autonomy at play within the family unit. Similarly, contrasting Alex and Mikael's experiences as children having their gender policed by their parents, the impulse to return to or escape from the family home can be better understood.

\section{The Promised Land}

In Transparent, the family home is looming and omnipresent. Built in the 1970's, Maura's home is large and spacious, with a pool in the backyard. Her home is far and away the most affluent one of all the works under examination. Maura's transition is closely linked to the sale of the family home (which she owns) and throughout the first season, the children fighting over the property rights is a key narrative theme. Although Maura is the owner, her children feel as though they have a proprietary right over their family home. In many ways, the family home represents the vestigial family unit, and specifically Maura's assigned identity. This is not a family that Maura was raised in but that she helped create as a co-parent. In some ways, then, her role is even more secured because she is one of the founding members of the family (specifically fulfilling the patriarchal role). This is where the ownership over the vestigial family home becomes especially significant. Where Maura is trying to escape the house by selling it and moving into a queer-friendly apartment, Ali, Josh and Sara who are trying to either claim it for their own families or profit off of its sale for their own gain.

In the premiere episode, the main point of tension is not that Maura comes out as transgender (which she tries to do) but that she curtly tells her children that she is selling 
the house: "I'm done with the house." For the spectator who is already familiar with the premise of the show (the poster features Jeffrey Tambour wearing makeup), this works as a misdirection because it is not the reveal we are expecting. This revelation of the house being sold (which Maura substitutes in place of coming out) is then closely linked to her transition. When she moves out of the home in which she raised her children and into the queer-friendly apartment, her movement from one space into another is also symbolic of her transition from one gender identity into another.

With this in mind, her children's reaction to the news of the house being sold is significant. "I'll take it," Josh says immediately, only to have Sarah interject with, "No you won't," before he makes an argument about how he's going to "flip it." They start to argue before Maura offers the house to Sarah, the only member of her family who is married with children: "I was thinking that you and Len would love to live in this house..." Passing on the nuclear home from one generation to another in this context becomes significant throughout the series. Maura is selling the family home because she wants to occupy her new gender identity. Ownership of the family home becomes a main point of contention between the characters throughout the rest of the series.

Even though Sarah initially seems like the most stable member of the family (because she's married with two children) her ownership of the traditional family home becomes complicated when she engages in numerous affairs. In the same episode, after her father tries to gift her the house, Sarah begins a lesbian affair with her former lover Tammy and they eventually move into the house together. Queer families occupying heteronormative spaces in order to make heterosexual people more comfortable is something that Sara Ahmed explicitly argues against in her chapters on comfort and 
space: "It is in 'not fitting' the model of the nuclear family that queer families can work to transform what it is that families can do. The 'non-fitting' or discomfort opens up possibilities" (154). Sarah and Tammy try to "fit" into the heteronormative family mould but ultimately they fail when Sarah has an affair with her husband. In this way, dysfunction is introduced even into the relationship of the most stable member of the Pfefferman clan. Even though Sarah is deemed "most fit" to own the family home in theory (because of her children), this is negated by her numerous affairs both in and outside of her marriage. Even though the traditional home has been the territory of the heteronormative nuclear family, even they can't coexist happily within it.

The symbolism of the family home and its connection to Maura is further complicated when Sarah's partner Tammy begins renovations. Both Ali and Josh are averse to Sarah taking over the family home, but Josh is particularly uncomfortable with it, especially when Tammy begins to remodel it after he expressly asks her not to in episode five. When he finds out in episode seven that Tammy has been renovating the house behind his back he turns on Sarah: "You had no right to let her do that- it's not your house." Josh's discomfort seems to stem from the idea of his family home being updated for a new, more modern family. He storms in and begins yelling about the changes: "Shit! That bitch did all this?! All the fucking wood is gone, all the fucking books are gone! And look! We have a beautiful plasma television set instead of a fireplace!" What becomes interesting is that Josh does not want to keep the house to live in for himself, but to sell it as is. "Preservationists are jizzing themselves for a house exactly in this condition," he tells Tammy in episode five. Josh is fighting to preserve and sell, where Sarah wants to update the house so she can move into it with her new partner 
and their children. Josh's fight to keep the house as it is also ties in with his reticence to accept Maura's felt identity.

Josh fights not only to preserve his family home but also to retain the stabilized heteronormative relationships within which he is comfortable. His discomfort becomes very evident when he visits Maura at her new apartment. On his way to find Maura, he is stopped by a bunch of gay men by the pool who start catcalling him and remarking on how good looking he is. Josh awkwardly waves them away. As a heterosexual, cisgender, white man, he is in the minority within that group and (based on his reaction) it feels unusual for him to be in that position, where he is the object of male desire, with his power momentarily overthrown. In episode six, he explicitly delineates the line between safe and unsafe spaces when he says that it is fine if Maura is trans so long as she only does it in private, or as he phrases it, "whatever people want to do behind closed doors." Motivated by his embarrassment, Josh implies that Maura can be free to act as a woman as long as she does not do so in public (heteronormative and therefore unsafe) spaces and risk exposure (and in doing so bring shame to the family). Even though he speaks out of shame, Josh references the different conduct that is tolerated in certain spaces. The disparity is clear: in the family home, Josh wields enough power to say with authority what changes should (or should not) be made to the home, but in Maura's apartment complex, he does not even feel comfortable engaging in a conversation with the other residents. Josh's fight to "preserve" the home also functions to retain the place where power relations are heteronormative and stabilized.

However, Transparent demonstrates that what is safe and comfortable for the children is not always safe for Maura, which is developed in her personal reactions to and 
memories of the house. In a flashback in episode two, a closeted Maura hides in her office and puts on a woman's blouse. Later, she returns from work, enters the house and kisses her children while Maura in the present watches from the driveway. Visually separating Prosser's "I" from the "me" (102) this scene demonstrates that Maura has been struggling to occupy her felt identity for a long time. This scene emphasizes how space affects a person's subjectivity. The house where her children grew up represents the seat of her patriarchal position. That Maura is selling the house at the same time as she transitions would suggest that the two events are interrelated.

The queer-friendly apartment complex that Maura moves into post-transition becomes a space of liberation where she can not only embody her felt identity comfortably, but analyze her positionality within her family. Even her exploration of her friend Davina's apartment in the second episode reflects the division between safe and unsafe spaces. In her description of the apartment complex she lives in, Davina tells Maura that it's okay to go into someone else's apartment because "we all take care of each other here." This demarcates the apartment complex as "safe" for queer bodies, filled with protection and unconditional acceptance that Maura lacks in her immediate family. Within the safety of Davina's apartment, Davina predicts that Maura's family will eventually abandon her. Once Maura moves into the queer-friendly building, her family registers it as a less comfortable space. Ahmed directly links bodies being comfortable to their ability to fit in spaces that are designated for them: "Comfort is the effect of bodies being able to 'sink' into spaces that have already taken their shape" (152). While Maura's family is not actively excluded when they visit the apartment complex, they do lose their privilege of being in the majority, and thus their comfort level is decreased. 
While the family home is no longer a place where Maura feels comfortable, it is far superior to the risks that are associated with the public spaces depicted in the series. In her book, Julia Serano breaks down the experience of a transgender person occupying public spaces in her commentary on public gendered bathrooms. When a friend asked her if she had ever wandered into a men's washroom by accident, Serano says: "I laughed and told him that there had never been a single instance in my life when I had walked into a public washroom ... by habit" (180-81). The majority of public spaces operate under the systemic assumption that the users will be cisgender and heterosexual.

As Serano specifically points out, public washrooms are a key example of spaces that are organized according to the gender binary. The implicit assumption is that people fit into only one of two categories: men or women. Or, as Sara Ahmed argues, "public spaces take shape through the habitual actions of bodies, such that the contours of space could be described as habitual" (156). Ahmed's use of "habitual" is an especially compelling word choice because it ties into what Serano terms "cissexual assumption," where cisgender people operate under the assumption that the people around them are also cisgender, unless they are explicitly confronted with evidence to the contrary (165). Public spaces such as gendered washrooms are created by a cisgender authority that assumes that all of the possible users will conform to one of two categories. As a result, these spaces are implicitly cissexist, and put trans people in a position where they must constantly be vigilant about the possible revocation of cissexual assumption at any moment when they occupy such spaces.

The very real dangers of cisgender perception become especially evident in public space. The organization of dualistic public spaces produces what Serano terms, 
"cisgender gender entitlement," which propels people, "beyond a sense of self-ownership regarding their own gender and broaches territory in which they consider themselves to be the ultimate arbiters of which people are allowed to call themselves women or men" (165). Maura is subjected to aggressive cisgender gender entitlement in Transparent when she goes into a public washroom with her daughters in episode four. Hesitant to even enter the space to begin with, Maura only enters the washroom because Sarah comes back out and leads her inside by the hand. Sarah is wielding her authority as a cisgender woman, demonstrating ownership over a public space, which comes into direct conflict with the cissexual assumption of privilege of another cisgender woman who feels that she too has ownership. Because Sarah is admitting her father into the space and closely associating herself with her, there is the presumption of Maura's safe inclusion. This scene makes it clear that Maura would never try to enter a public female washroom alone, without the protection of cisgender companions.

That this scene occurs so quickly after she comes out to Ali would suggest once again that the series is not concerned with Maura's experience of the space (she knows enough to be reluctant to enter the space), but her daughters' limited experience encountering the transphobia of other women. Significantly, the woman who demands Maura leave the space is only brought into the interaction by her teenage daughters who whisper, "Isn't that a guy?" Within the interaction, the woman claims she is protecting "young women in here who he is traumatizing." Sarah rushes to her father's defense, calling the girls "snickering bitches" and saying, "This is my father and he's a woman!" Even in her nobly intentioned defense of Maura, Sarah slips in her language and uses a male pronoun when talking about her. The stranger in the washroom commands a 
position of authority because she reads Maura's body as male and refuses to grant her cissexual privilege. Soon, the entire interaction spirals into familial connections. The woman says: "You don't talk to my children that way!" Sarah replies: “And you don't need to talk to my father like that!" As the argument escalates, the camera focuses in on Ali through the bathroom stall as she overhears the interaction and closes her eyes, embarrassed. This entire scene is a demonstration of cissexism that Serano describes in her book: "Once a cissexual assumes that their gender entitlement is a birth privilege, then it becomes easy for them to dismiss the legitimacy of transsexuals' identified and lived sex" (168-69). When Ali emerges from the bathroom, she asks Maura, over the fighting women, if she still needs to use the washroom, but Maura refuses.

Transparent depicts transphobia as being an internal process as well as an external one. Even though they rush to her defense, in the parking lot after the bathroom confrontation, it is Maura that Sarah and Ali blame. As they walk away, Ali says: "Why is he doing this now?!" And Sarah replies, "Why did he wait so long?!" Her daughters' reaction suggests that they blame Maura for the altercation in the bathroom more than the transphobic woman. The next scene shows Maura at home alone in her apartment, recuperating from the traumatic ejection, listening to a raucous party occurring next door. Trying to get them to quiet down, she initially is very feminine in her pleas, touching her throat and keeping her voice high pitched and soft. After a few minutes of being ignored, her frustration kicks in. She abandons her attempts at feminine meekness and shows rage, beating the balcony partition with her shoe, yelling and cursing at them to "Turn it the fuck down!" With this scene (the private reaction to the public humiliation), it becomes clear that Maura only feels safe expressing her public frustration within her domestic 
environment. Her only recourse in the bathroom situation is to flee, which is what she does, but she vents her anger within the walls of her home. Even in the first moments of her appeal for her neighbours to be quiet, she goes to great lengths to police her voice and her body so that they will be read as feminine. However, when no one listens to her, and the raucous party continues, she begins to scream at the walls. Only when she is completely and utterly alone does she allow herself to show rage, and that rage is aggressive, gendered more masculine. She continues to scream, calling the partiers "faggots" and saying that they "are not the only people in the fucking world! You aren't alone!" before exhausting herself and sitting alone on her balcony, listening to the party that is happening without her. Her use of a homophobic slur in this place of relative queer safety to vent her frustration is very telling of the homophobia that is intrinsic to dominant, heteronormative Western culture. The tools she uses to vent her rage operate according to a similar mechanism of oppression that have recently been used against her.

Maura's actions are radically different in the public versus the private sphere, and her conduct speaks to certain insider behaviors that are tolerated within a community that would not be accepted outside of it. Maura feels safe being angry at the residents of her apartment complex because she feels as though she belongs in that space. Yet, even though this is the case, she is still left at the end of the scene all by herself, forced to listen to a crowd of happy people at a party to which she is not invited. The symbolism of the outsider here is self-evident. As Sara Ahmed argues, "Spaces are claimed through enjoyment, an enjoyment that is returned by being witnessed by others" (165). As Maura listens to the revelry of her queer neighbours, her exclusion is underscored not only by her lack of pleasure when theirs is clearly present, but also by their indifference to her 
agony. Similarly, Maura's experiences at cross-dresser camp signifies a different kind of insider-based safety, in the communal outdoor space where people partaking in a certain unifying activity (cross-dressing) are granted access to specific spaces based on their inclusion in the group.

Implicit codes of conduct are made explicit when Maura violates the unspoken rules of cross-dresser camp by leaving the camp still in women's clothing. When Marcy (her best friend/fellow cross-dresser played by Bradley Whitford) gets upset because Maura's still dressed as a woman, Maura turns on her angrily and says: "This makes me happy!" For Marcy, Maura is betraying the space by refusing to adhere to the rules that certain styles of dress are for certain spaces. Furthermore, Maura is inviting ridicule by continuing to present as a woman outside of the predefined safe space. Marcy is experiencing the same pre-emptive embarrassment that Josh voices. By defying the rules of insider space and carrying on as a woman, Maura owns her subjectivity and refuses shame. Her defiance also exposes that shame and secrecy are the structural foundation of the cross-dresser camp community: a place where they can dress however they choose, but they must leave restored in their assigned gender roles. By making cross-dressing an escapist destination, it implies that there is something about gender non-conformity that must be cloaked or hidden. Cross-dressing is an escape not just of place, but also temporally: those who vacation at the crossdressing camp do not associate crossdressing with their everyday routine.

The series also explores divisions within the queer community. The argument between Marcy and Maura represents a rift in their experiences and the establishment of a hierarchy between transvestites (people who dress up as another gender for pleasure) and 
transgender people (people who identify as genders other than what they were assigned at birth). This hierarchy is made explicit in episode eight when Jackie (a fellow crossdresser played by Pat Towne) gossips with the group about "Ramona," a former crossdresser from the camp who decided to transition and was forbidden from returning. “Good riddance!” Jackie scoffs to Marcy and Maura, "We are crossdressers but we're still men!” The word choice suggests that cross-dressing is seen as a temporary escape, which Jackie considers a preferable alternative to actually living and identifying as transgender.

In closing, a great deal of Transparent is spent exploring the intangible relationship of space and comfort that Maura experiences, both inside and outside of her family home. Many of the storylines between the children rely on fights that are either directly or tangentially related to the sale of the house. By depicting her transition as a foil for moving out of the home where she raised her children, Maura moves out of one space and into another, while experiencing a similar movement between her assigned and felt identities.

\section{O Mother Where Art Thou?}

52 Tuesdays uses the home space in a similar way; the trans person is in control of who can access the space. However, as was demonstrated by Maura in Transparent, having control over the space does not guarantee James safety or freedom of expression. In fact, Billie punishes James by beginning to rebel after he banishes her temporarily from his home. Rather than moving when he decides to transition (like Maura does in Transparent), James instead moves Billie - he sends her to live with her father, Dan. Even though it is temporary, Billie (who controls the camera's gaze for two thirds of the 
film) feels this is as a banishment from her mother's life. In 52 Tuesdays, the family home becomes emblematic of the parent-child bond. We do not see the home through James's gaze but through Billie's, as a place that (from the very beginning of the film) has betrayed her by "abandoning" her.

From the very beginning of 52 Tuesdays, the family home that Billie shares with James and his brother Harry is characterized by conflict. A one-story, three-bedroom bungalow in the middle of suburbia, the film takes care not to specify the exact location of the events. Even though it is shot in Adelaide Australia, there are no references to any landmarks or institutions that are distinctly Australian. Decontextualizing the events by placing them in a nonspecific suburban area works to signify that these events could be happening anywhere. The first scene of the film (described in chapter one) shows Billie entering the house to find James shaving his head and wearing a binder. Following this revelation, the scene immediately switches to Billie angrily packing while James tries to explain, "You don't have to leave right now, can we sit down and talk about it?" But Billie is dismissive: "I get it- you feel like a man, you want to become a man, you need a little space." The film begins the narrative in this way, with the home being a place from which Billie is forcibly ejected. Furthermore, it is often the trans or queer person who is forced to move by their cisgender parents. This characterization of the home as a site of aggression is further validated as the film continues, with the family home being the place where most of the confrontation and conflict occurs. For James, the home is a rehearsal space just as the bathroom and bedroom are for Mikael in Tomboy. Billie does not look at James' home as a welcoming hearth so much as a battleground, where wounds can be inflicted and incurred on all sides. 
When Billie moves to Dan's house, her living arrangements go from stable and fixed to transitory and perpetually in flux. While most of the film takes place at James's house, there are a few allusions to Billie's experience at Dan's house, which is largely characterized as a place of rebellion and defiance. In one of the scenes following James's mastectomy, Billie and her friend Josh (Sam Althuizen) are in her bedroom, naked and stoned when Dan knocks on the door, demanding to know why Billie isn't with James. "James doesn't need me...there are plenty of others," Billie scoffs, before warning her father with a laugh, "Don't you try and trick me again, picking me up after school and taking me there. Hijacking me or something, scooter chef man!" Her blatant disobedience to her father (and his refusal to actually enter the room and punish her) suggests the surplus of control Billie has access to when James is not on the scene. Billie also says this with an attitude; she is vengefully punishing James by abandoning him when he is vulnerable, the same way that he blindsided her with his transition and asked her to move out. Billie's life at Dan's house is constructed as being chaotic and fractious (at least in comparison to Billie's life in the past).

When it becomes clear that Billie is not really welcome in either of her homes, she turns to the abandoned warehouse to which her uncle Harry has granted her access. Over the course of the film it becomes a site of sexual exploration, and a communal space that she can share with her friends. While contradicting the idealized conventions of the familial home, in 52 Tuesdays the domestic becomes a place of stasis where creativity and experimentation are stifled, while the warehouse is where Billie and her friends try new things and experiment sexually. Unlike Transparent, where the family home must be escaped so that transitioning can better occur, in 52 Tuesdays the home represents the site 
of the gender transition. Billie feels no ownership over the home because it, like her mother, has betrayed her. Compellingly, there are few scenes that take place in Billie's father's home. Instead, the majority of Billie's experiences are based in the in-between spaces at school and in the warehouse. While her mother transitions gender, Billie's entire life is one of being constantly in transition from one space to another. Yet, because her mother is the parental authority figure in her life, Billie is moved initially at James's demand. However, once she begins to establish authority over different spaces (taking ownership of the warehouse is one key example), she starts moving based on her own desires. Billie even hints at this during her outburst in the therapist's office "I've been spending hours God-knows-where without anyone knowing where I am." In this outburst, Billie references the autonomy she has been granted in her mother's absence. Able to control her own schedule because of the shifts of guardianship, Billie points out her own power to deceive as a result of James' lacking parenting skills.

For his part, James is almost exclusively shown within the domestic sphere of the home. The audience is encouraged to associate him closely with the one-story bungalow Billie grew up in. Even when he is in spaces other than his home, James is mostly shown inside various spaces. Indeed, the only time that he seems to actually be outside is during Christmas break when the family goes to the beach and he confides to Billie that he is allergic to the testosterone he has been taking. He is showcased so much within the domestic because that is how Billie sees him. Within his home he has complete control over his surroundings. His power over the space is similar to his power over his daughter, until she begins to rebel. 
The conclusion of 52 Tuesdays brings the dialectic of space and relationships full circle. In the end, Billie ultimately agrees to return home, and the last scene of the film is her showing up on James's doorstep with a suitcase and ringing the doorbell. When he opens the door and lets her in, the last frame is of the house, suggesting that they have both decided to cohabitate and work on their relationship. In effect, James is deciding to be a full-time parent again, while Billie is finally respecting the process of his transition. At the beginning of the film, James chooses his transition over parenting Billie and this choice is understood by Billie as being a selfish one. In the end, he asks her to move back and, after a sustained period of consideration, she agrees. The house is once again a place of collectivity, if not harmony.

In 52 Tuesdays, James struggles with some of the same dichotomies of power, space and freedom that Maura does in Transparent. Both depict transitioning parents contending with children who feel as though they have proprietary rights over the familial space. Maura and James both individually struggle with asserting their own rights to personal space. For Maura, that means leaving the home for a new space, while James has to modify and update the old one, creating it as a space where his felt identity can thrive. Both Maura and James enjoy the adult power and bodily autonomy that Mikael and Alex seek in their respective films, but these liberties come at the cost of their previously stabilized familial relationships. In the rest of the chapter, I will take up the issue of the lack of power and freedom that the adolescent protagonists of both $X X Y$ and Tomboy struggle with in their respective spaces. 


\section{Into The Woods}

Much like Maura in Transparent, Mikael in Tomboy has to occupy a new space to fully experience his felt identity. However, because he is a child and his assigned identity is heavily policed by his parents at home, he must find a different space for his felt identity to thrive. Like Maura, Mikael's identity is inextricably entwined with space. When he first goes outside and meets Lisa, she asks his name and he immediately says "Mikael." These two events are then interconnected and from this point forward, Mikael lives his felt identity in the outdoors with his friends and adheres to his assigned gender and name at home. Whether the space creates the identity or the identity creates the space is unclear, but the separation is resolute and immediate. His home becomes the space that he is initially trying to escape. Mikael spends a great deal of the film contending between the different, ever-changing requirements of two spaces (the indoors and the outdoors) as he tries to discern where true freedom really lies.

Tomboy begins, much like Transparent and 52 Tuesdays, with movement. The film opens with Mikael helping his father move the family from one home to another. Going to get the last of the boxes from the old house so they can bring them to the new one, the family home is represented as being in transition. Father and child joke around as they move, exploring the new space. A towering apartment complex crowded with people, the family's new home brings with it the promise of interaction with new people. At the end of the film, right before his mother reveals his assigned gender to their neighbours, Mikael begs his father to move the family once again: "We have to leave. Please." His father refuses, and Mikael is forced to stay in the apartment. Mikael, as the 
child, lives his life at the whims of the adults in his life. He does not have access to the same power and bodily autonomy that James and Maura have.

From the beginning, the film establishes a very clear dichotomy between the liberating wilderness and the imprisoning, crowded apartment complex where Mikael's family lives. In the apartment, he must respond to his assigned name and (in front of his parents) enact his assigned gender, but in the woods near the apartment complex he can be free. From the very beginning of the film, as soon as Mikael enters the outdoors, it is rife with possibility and the freedom of self expression. However, with that freedom comes an enhanced sense of risk, which foreshadows the eventual exposure of Mikael's assigned gender.

Much of the suspense in Tomboy arises from the fear of Mikael's assigned identity being discovered. Over the course of the summer, Mikael becomes susceptible to the risk of accidental exposure. Most of the time, he is able to avoid this by appearing reticent to engage in activities. For example, on the first day when the other boys are playing soccer and removing their shirts, Mikael stands on the sidelines, watching them intently. That night, he scrutinizes his chest in the bathroom mirror, trying to discern if it looks appropriately masculine. Satisfied, he removes his shirt and joins the game the following day. However, there are instances where Mikael is unable to rehearse his masculinity and is forced to improvise. On one of their outings into the woods, Mikael has to relieve himself covertly, away from the other children. When another boy stumbles onto the scene, Mikael hurries to cover himself and in the process gets covered in urine. The boy points this out to the other children and they laugh at him. This scene is captivating because it keeps the audience in suspense until the last possible moment. Just 
like Mikael, we do not know what the boy knows, or how much of Mikael's body he has seen. There is a close up of Mikael's face and then the sound of a branch snapping. The camera jumps suddenly to a long shot of the boy standing behind him. Just like Mikael, the spectator cannot know how much has been seen and whether or not his secret has been discovered. Working to heighten the tension, the outdoors becomes a minefield of rewards and risks. For every stolen kiss with Lisa, there is an event like the bathroom mishap.

The probability of Mikael's assigned gender being accidentally discovered increases as the summer progresses. Additionally, things become more complicated as Mikael gets entangled in the social dynamic of the group. This ultimately means that he is less and less able to control the scenarios in which he finds himself. As the summer continues, the masculine behaviors that Mikael performs become less optional and increasingly mandatory. As described in chapter two, the film takes Mikael's felt identity seriously for most of the film and this is reflected in the formal elements. However, the more time that Mikael spends in the liberating wilderness, the more that is required of him. The cissexual assumption that is extended to him is conditional, and the more liberated he feels, the more dangerous the risks of getting caught become. Mikael depends upon the home space for the privacy it provides and for the ability to rehearse his masculinity (for example, by fashioning the packer out of plasticine). It is only after much practice and modelling that he goes to the lake and swims and wrestles with the other boys. This rehearsal is necessary to avoid exposure in the potentially treacherous world of the outdoors. While the outdoors initially seems free, it becomes increasingly 
dangerous as Mikael spends more time there. As the risk potential of the outdoors is heightened, the recovery potential of the home is also developed.

While the outdoor space is where Mikael can debut his felt identity, the indoor space of the home has less obvious freedoms of its own. Chief among them is the freedom of the body. As was mentioned in chapter one, we see a full frontal view of Mikael's crotch early into the film, as he is getting out of the bath. Alone in the bathroom with the door closed, he stands up confidently and without embarrassment. This demonstrates that in the home, he does not have the same need to hide or obscure his body as he does in the wilderness. Much like the earlier scene that accompanied the football playing, the swimsuit and packer are constructed within the safe rehearsal space of the interior. Home is the place where he stands in front of the mirror and scrutinizes his reflection, trying to make sure nothing gives his assigned identity away. In the home, he is free to (privately) experiment with and sculpt his felt identity. This is partly because of the lax way he is parented over the summer. It may in be connected to French parenting norms, or perhaps be because they are distracted by the anticipation of the birth of another child, but the parents are very absent in Tomboy. This is a far cry from the typical Western depiction of "helicopter" parenting, in which the parent is constantly hovering over and policing the child. So while his gender is more or less policed by his parents at home and he is forced to answer to his assigned female name, home provides certain comforts that the dangerous yet liberating outdoor space cannot.

Both the home and the outdoor space rely on cisgender assumption. Serano defines cisgender assumption: "When a cissexual makes the common, albeit mistaken assumption that the way they experience their physical and subconscious sexes... applies 
to everyone in the world" (164-65). Both the family home and the child-dominated society in the wilderness work under the assumption that everyone has the same experience of gender. Mikael is allowed into the secret children's world of the wilderness because they automatically read his body as male. Similarly, in the home space, because Mikael does not make any dramatic changes to his costume or hairstyle, the parents assume that he is presenting himself the way he always has. In this sense then, Mikael uses a costume (described in chapter one) that is functional in both spaces.

Much like in Transparent, where the family house functions as a stand-in for the familial unit, Tomboy's apartment complex is strongly symbolic. The building in which they live is tight and compact, with many families living on top of each other. Living in such close quarters with so many people supplies the threat of Jeremy Bentham's "panopticon," which Michel Foucault describes in his book Discipline and Punish: The Birth of the Prison. A panopticon is a prison constructed with the cells in a circular model with the guard at the center, so that everyone may be monitored at all times: "He is seen, but he does not see; he is the object of information but never a subject in communication" (200). The purpose is to make the subject feel as though they are always being watched (even if they cannot know for sure). As Foucault argues, the threat of the panopticon is "to induce in the inmate a state of conscious and permanent visibility that assures the functioning of power" (201).

In Tomboy, Mikael's mother ultimate parades Mikael around the apartment complex in a dress, attempting to "correctly" gender him because she cannot know exactly when or how Mikael was seen. She seems to do this not out of malice but out of fear of the other possible consequences of people realizing that Mikael has been 
presenting his felt rather than his assigned identity. Mikael's mother's fear lies in the possibility of surveillance that the structure of the apartment complex invites. She does not know definitively whether Mikael has been spotted and flagged by the neighbours, but according to the rules of the panopticon she must operate as though he has, and disciplines him as a result. She polices her children's bodies more harshly in the public eye than she does at home. This is evinced by the casual way in which she handles Mikael's costume and dress style in the majority of the film. While the family is alone, the mother does not seem to care, and since she is on bedrest for the majority of the film, Mikael is free to do as he pleases.

Ultimately, Tomboy depicts Mikael's experiences within his family home as being both restrictive and comfortable. Even though it is his mother who punishes him, Mikael recuperates with her and the rest of his family at home after he is humiliated. At the end of the film, it is within the family home that he sequesters himself, reveling in the protection of his family. While he rebels against the gender policing of his parents, he is free to return to the home to recover (something adults like James and Maura do not feel free to do). The outdoor space, while initially inviting because of its potential for liberation, ultimately betrays him, and he is only able to return to it when he has been reverted back to his assigned gender.

\section{In the Garden of Evil}

Even though they are older than Mikael, Alex in $X X Y$ also has the precarious task of balancing the desire to stay in the freedom of the dangerous outdoors versus the known, restrictive, regulated world of the home. Alex spends most of their free time in $X X Y$ trying to escape their family home into the solitary nature that surrounds it. 
However, when the wilderness betrays them with the presence of predators, their family home is the only place that they can turn for refuge. The family home in $X X Y$ is a place for conflict if only because it is the place where strangers (i.e. Alvaro's family) are invited. Specifically, the home space contains certain dangers initially when Alex is at risk of gender policing and surgery. When Suli and Kraken invite Ramiro (the cosmetic surgeon) to stay at their home, his visit signifies the suggestion of Alex's bodily modification through surgery. Additionally, other people outside of the home are threatening because of the potential for them to become aware of Alex's difference even if Alex does not choose to explicitly reveal it.

Alex's preference for the natural world is linked to their gender identity from the beginning of the film. This is a clear difference between $X X Y$ as an intersex film and the rest of the audiovisual works detailed in this chapter: nature is constructed as an arbiter of truth. In her analysis of $X X Y$ and Fish Child (another film by Lucía Puenzo), film scholar Margaret Frohlich makes the argument that both of Puenzo's films constitute bodies as a products of the natural world, and in claiming this naturalness, they defend their right to exist (160). Frohlich goes on to argue that in $X X Y$, the film "ultimately prioritizes nature over agency; the right choice is the natural choice" (161). In this case, $X X Y$ constructs Alex as being a product of the natural world by constantly showing them alone and at peace in the wilderness.

Unlike the traditional homes in Tomboy and Transparent, in which the family home is a structure where familial interactions take place, $X X Y$ alters the boundaries of the conventional home. The physical home site is a secluded cabin, on the back of a large property, surrounded by nature. Alex spends most of their private time on the property 
around the house, not just within its walls. Thus, the wilderness surrounding the actual structure becomes an extension of the family home. The boundaries of this space are explicitly marked. When Alvaro and his family arrive, we watch Alvaro getting out of the car and opening a gate to Alex's family's property, which bears a sign that reads "Prohibited to Pass." The remote location of the family home, working in tandem with signs that explicitly forbid entry, construct Alex's domestic environment as some sort of wilderness preserve. Alex spends a great deal of time alone in the wilderness. By constructing the home and the outdoor space as inextricably linked, the film dissolves conventional associations of the indoor/outdoor binary. This also means that the boundaries of each space are unclear. The outdoor space is also the home space: so inherently safe for Alex that they have no way of predicting that nature will eventually betray them, by being the setting of their sexual assault.

Indeed, most of the film shows Alex as comfortable and safe in nature, swimming alone in the bay and taking long solitary walks on the beach. Nature is so strongly associated with tranquility that it is startling to both Alex and the spectator when interlopers invade the scene and suddenly the space becomes dangerous. Walking alone on the beach, Alex does not immediately notice the sound of a motorboat cruising towards the shore. The camera sees that this boat is filled with a trio of young men, eager to reach land. Finally noticing them, Alex pulls up their hood, hiding their face as they steadily increase their pace. Over their shoulder, the naked torsos of the boys get closer, as they call out for them. Soon Alex is overtaken and the boys become aggressive, clutching their shoulders and touching their body. A three-man army, they force Alex towards the sand dunes and away from the camera which lingers by the shore. The four 
figures get smaller against the natural background and the scene becomes overtly precarious. The boys are predators and Alex is their prey.

Maintaining a distant but keen eye, the camera watches from far away as Alex unsuccessfully struggles to get away, fighting back until they are forcefully restrained by their captors. Entrapped and clawing to get away, the sand dunes imprison Alex as their captors pin them down. Sobbing, Alex fights back and begs to be released but the boys are unrelenting, cursing as they demand to see Alex's crotch and pulling down Alex's pants. Restrained and laid bare on the ground, the camera is trained on Alex's face as their pained eyes glaze over, looking at the sky as the boys begin to abuse their body, dissecting them with their gaze and molesting them with their touch. Unlike in Tomboy, where we only see Mikael process his humiliation afterwards and in an extreme wide shot, in $X X Y$ the spectator is forced to watch every minute of Alex's assault. Once they move into the sand dunes, the scene is captured in medium shots and close-ups, as the boys focus only on their body, the camera fixates on Alex's face, which keeps the thematic focus on their subjectivity.

Indeed, where Mikael finds freedom in his ability to go outdoors and meet people under his felt identity, Alex finds freedom in not having to be around people in the outdoors. Where Mikael's felt identity finds success being in the wilderness and having people read his felt identity correctly, Alex is most comfortable when they don't have to meet anyone's expectations. Where Tomboy represents the outdoors as being crowded with unknown strangers (which is where both the risk and reward arise), $X X Y$ represents the wilderness as only being dangerous when other people are present. During the scene where Alex is attacked on the beach, they are pinned down to the sand dunes by the gang 
of boys. When Alex tries to escape by clawing their way up the sand dune, the sand falls apart in their hands, keeping them secure while the boys molest their genitalia. In this scene, the nature that was once so welcoming turns on Alex, just as it does on Mikael in Tomboy.

Unlike Maura in Transparent, in $X X Y$ Alex does not actively pursue interactions with family and friends; if anything, the opposite is true. Alex uses the wilderness as a way to escape the opinions of family and friends. When they are with other people (either familiar or strangers), the issue of their body becomes omnipresent. However, after they are assaulted, it is to their family that they rush, and the comfort of their family home. Lying in bed in Suli's arms, it is here that Alex finds their family's true support. Alex is experiencing a classic war with the nest that most adolescents experience; wanting freedom but needing the security of their family. The exception, of course, is that Alex's intersex body puts them at risk of violence, particularly in a small town. Indeed, even though Kraken says that they left the city to escape "certain attitudes," there is no indication that these attitudes do not exist in the small town. Indeed, if anything, the people of the town seem to be more conservative in their ideas regarding gender than others. The only reason why the space might be moderately more understanding is that it features a smaller population separated by greater distances so there is the possibility of seclusion. Indeed, many of the shots of Alvaro's family arriving at Alex's home suggests that it is far removed from other spaces. There is even a gate that wards away outsiders. So while Kraken has been able to save his family from the direct presence of people, he has not saved them from the intrusion of their opinions. 
In $X X Y$, Alex finishes the fight for bodily autonomy that Mikael in Tomboy is only just beginning. Both of them grapple with the same pre-pubescent struggles of being brought up within and constrained by a heteronormative family dynamic in which their felt genders and sexes are policed. Watching these films in tandem, the enormous power of the gender policing by the parent figures becomes tangible, but so does the value of independent subjectivity. Mikael and Alex, in one way or another, are asserting themselves at an early age by trying to enact and live as their felt gender (something both James and Maura lament that they could not do).

Reading $X X Y$ and Tomboy in conjunction with Transparent and 52 Tuesdays, it becomes clear that the fight for bodily autonomy is a lifelong battle both inside and outside of the family home. Even James and Maura, the parental characters who have the power and independence that the adolescent characters crave, do not have complete control over their homes, nor are they completely safe. Similarly, Mikael and Alex exhibit prescience in trying to enact their felt genders, but they too are at risk of the prejudices of those around them. The responsibilities and burdens of the parent are measured against the imprisonment of the adolescent. Transitioning into a felt sex or gender complicates the dynamic both within and outside of the family home.

\section{Conclusion}

In this chapter, I have demonstrated the complex and nuanced ways in which transgender and intersex protagonists interact with their family homes both symbolically and in the literal site. Through the comparison of the construction of different kinds of homes and the various interactions that happen there, it becomes clear that the divide between the indoors and the outdoors does not necessarily suggest safety or danger. 
Different spaces host a variety of risks, and this in turn, has an effect on how the protagonist is able to self-fashion. While the family home (in which the assigned gender is normalized) might be a space of conflict, it may simultaneously be a place of recovery and refuge.

Similarly, while outdoor spaces largely represent freedom and escape from gender norms, the wilderness can also represent unforeseen dangers and the risk of exposure. The way that different spaces are depicted is intrinsically connected to the way the camera sculpts the characters' felt and assigned identities in their experience of that space. The family home produces the subject who produces the gender and all of this is represented by the camera. The end result is that no space is ever really safe or unsafe for a transgender or intersex protagonist in and of itself; it is the people sharing that space where the danger exists. 


\section{Conclusion}

"It is revolutionary for any trans person to choose to be seen and visible in a world that tells us we should not exist"

- Laverne Cox, March 16 ${ }^{\text {th }}$ 2014, Interview with Buzzfeed Magazine

In 2016, the visibility that Laverne Cox describes is still revolutionary.

Mainstream audiences may be more comfortable with images of trans people, but the methods used to depict trans protagonists are still controversial. The audiovisual works I have analyzed use a wide variety of techniques to present their protagonists' felt genders. From Maura's use of costume and language, to James's pursuit of surgery, Mikael's demonstrations of masculinity, and last, Alex's provocation of the cissexual people around them, each character embodies their felt gender differently. This difference and variety is also apparent in the home space of each individual. An apartment complex, a mansion, a cabin far removed in the wilderness and a bungalow in suburbia - transgender and intersex characters are found anywhere and everywhere, regardless of how the camera chooses to depict them.

My main research questions interrogated how contemporary cisgender-made films and television shows direct the viewer to look at and listen to the transgender and intersex body. Further, what are the political and social ramifications of these aesthetic and narrative strategies? I have examined three different ways in which transgender and intersex protagonists are fashioned in contemporary international cinema: through selfrepresentation, by the camera and through the diegetic home. Chapter One was concerned with the methods of self-fashioning under taken by each protagonist: Maura uses 
language, James pursues surgery, Mikael demonstrates physical ability and Alex attempts to provoke those around them.

However, it becomes clear in Chapter Two that all of these attempts at selfrepresentation can be useless if the camera depicts characters' assigned identities as more authentic than their felt identities (such as in Transparent and Tomboy). Alternatively, Chapter Two also proves that if the camera aligns itself with the character's felt identity (such as in 52 Tuesdays and $X X Y$ ) the spectator is encouraged to invest in the protagonist's subjectivity. Lastly, Chapter Three explored the diegetic home spaces that produce each character (a cabin in Uruguay, a mansion in Los Angeles, an apartment in Lyon and a bungalow in Adelaide). It became clear that while the wilderness, like the home space, can be at turns dangerous or inviting, neither space is entirely safe for trans and intersex protagonists at all times.

Working in tandem, all three chapters have proven that the cisgender filmmaker has a clear impact on how the spectator looks and listens to the transgender or intersex body. The significance of these findings is that mainstream cisgender filmmakers have the ability to influence public perception of transgender or intersex bodies. Furthermore, these findings demonstrate that political progressiveness is not solely determined by narrative content; readings of bodies are also influenced by formal structure and interactions within the diegetic world.

When the cisgender filmmaker has such a substantial impact on the ways in which transgender and intersex bodies are read, the politics of representation come into question. In 2016, when images of transgender bodies are inundating the media, cisgender filmmakers have an ethical and moral responsibility to position themselves in 
relation to their content. It is far too easy, in the current moment, for a filmmaker to claim a politically progressive stance by featuring a trans character, and then providing a reactionary or overly simplified depiction. In the current moment, the critique of this practice is confined chiefly to the transgender community.

However, when cisgender filmmakers are telling transgender stories to widespread, mainstream audiences that are mainly comprised of cisgender audiences, this is not enough. There must be critique from both trans and cinema scholars alike, in order to bridge the gaps in discourse that currently exist. When cisgender people talk to each other about transgender or intersex experiences, there is a danger of straying into the ethnographic and in doing so, stabilizing the gender experience of "the other." Trans and intersex films that are actually made by trans and intersex people are largely confined to indie and LGBTQ2 festivals and the cisgender-produced models (such as the films I have explored in this thesis) are given a much greater visibility. The people represented on screen must be given the reins in order to sculpt their own representation. Both trans and intersex people must have the opportunity to share their experiences on whichever platforms they choose, by whatever means in which they can engage. I believe that the first step towards this change is by having cisgender filmmakers recognize and acknowledge their own position of privilege in relation to their subject matter.

Critically analyzing these works in relation to their cinematic predecessors proves that mainstream media is making incremental steps towards depicting transgender and intersex bodies in more authentic and politically progressive ways. In the future, it would be a worthwhile undertaking to contrast the representations of transgender and intersex bodies in the Western world with films from the East, such as Farewell My Concubine 
(Chen Kaige, China, 1993), Beautiful Boxer (Ekachai Uekrongtham, Thailand, 2003) and Jellyfish (Rosie Haber, Borneo, 2014). Additionally, an entire project that solely takes on South American depictions of transgender and intersex experiences would be fascinating, as would a project devoted solely to the differences in depiction between trans men and trans women. Lastly, investigating the question of race in relation to all of these methods of depiction and production would be critical. Specifically, focusing on the differences in representations of domestic spheres of white trans people versus their minority counterparts would fill some of the gaps in research that currently exist. Investigating the various ways in which the body is produced and then read in different racial contexts represents an area that needs to be expanded upon in current academic discourse on transrelated media. Expanding upon the work of scholars like Sarah Lamble, Anne Enke, and Viviane K. Namaste would provide a basis in understanding how racialization intersects with the production of transgender bodies.

There is a promise of change to come. Since I started writing this thesis two years ago, Tangerine (2015) made international headlines for featuring multiple trans actresses as did the online series HerStory (2015), an online series which was created by a transgender director Sydney Freeland. Both Tangerine and HerStory feature trans women of colour in protagonist roles. Slowly but surely, we are beginning to see transgender filmmakers and their stories be accepted into the fold. At long last, we are seeing those within a minority coming into their own and producing their own narratives. As scholars, we have not only a right but a responsibility to document and analyze the way that this is happening. 
XXY, Tomboy, 52 Tuesdays and Transparent are all cisgender-produced works that feature markedly diverse interpretations of the trans experience. The protagonists of these contemporary international audiovisual works self-fashion in different ways and have to interact with unique home environments. Their experiences of oppression and intolerance by the cisgender mainstream unite these characters, both publically and privately. So while these works are more nuanced and complex than their cinematic predecessors of the 1980s and 1990s, these works indicate the systematic oppression that gender non-conforming people continue to experience. From a cinematic standpoint, there is the opportunity to shed light on trans and intersex issues, and as far as we have come, we have much further left to go.

The sun sets over the ocean as a small ferry leaves the harbour. Wiping away tears, Alex jogs along the dock, catching up to Suli and Kraken who are slowly making their way back to the car as soft, melodic guitar music plays. It is a bittersweet moment. Ramiro, the cosmetic surgeon who wanted to perform surgery on Alex is gone, but so is Alvaro, the boy who loves Alex. As the trio walks along the dock under the setting sun, Alex takes Kraken's arm and wraps it around themselves. Father and child walk along like this, in a half embrace of unspoken, unconditional love and the camera moves to ocean and fixates on the horizon. Everything is going to be fine. 


\section{Bibliography}

Ahmed, Sarah. The Cultural Politics of Emotion. Edinburgh: Edinburgh University Press, 2004. Print.

Ames, Jonathan. Sexual Metamorphosis: An Anthology of Transsexual Memoirs. New York: Vintage, 2005. Print.

Amin, Kadji “Temporality” Duke University Press. Transgender Studies Quarterly 1 (12). (2014): 219-222. Web.

"Arrested Development" IMDb. IMDb.com, 2 Nov. 2003. 04 Apr. 2016. Web. $<\mathrm{http}: / /$ www.imdb.com/title/tt0367279/>.

Bornstein, Kate. Gender Outlaw: On Men, Women, and the Rest of Us. ed. New York: Vintage Books, 1995. Print.

Butler, Judith. Gender trouble: Feminism and the Subversion of Identity. New York: Routledge.1999. Print.

Enke, Anne. Transfeminist Perspectives. Temple University Press. Philedelphia. 2012. Print.

Foucault, Michel. Discipline and Punish: The Birth of the Prison. 2nd Vintage Books ed. New York: Vintage Books, 1995. Print.

Frohlich, Margaret. "What of Unnatural Bodies? The Discourse of Nature in Lucía Puenzo's XXY and El Niño pez/The Fish Child." Studies in Hispanic Cinemas 8.2 (2011): 159-74. Web.

Halberstam, Judith. "Posthuman Gender in Jonathan Demme's The Silence of the Lambs" The Transgender Studies Reader. Ed. Susan Stryker and Stephen Whittle. Routledge Press. New York. 2006. 574-583. Print.

"Housing and Homelessness" National Center for Transgender Equality. 2015. Web. 04 Apr.2016. <http://www.transequality.org/issues/housing-homelessness>

Horak, Laura. "Trans on YouTube: Intimacy, Visibility, Temporality" Transgender Studies Quarterly. 1 (4). (2014). 572-585. Web

Jones, Saeed. "Laverne Cox Is The Woman We've Been Waiting For" Buzzfeed.com. Mar 16, 2014. 04 Apr. 2016. Web. <http://www.buzzfeed.com/saeedjones/lavernecox-is-the-woman-weve-been-waiting-for\#.pt1LwxlGl>

"Klinefelter Syndrome." Genetics Home Reference. U.S. National Library of Medicine, Jan.-Feb. 2013. 04 Apr. 2016. Web <https://ghr.nlm.nih.gov/condition/klinefeltersyndrome $>$. 
Kuhn, Annette. The Power of the Image: Essays on Representation and Sexuality. London. Routledge Press. 1985. Print.

Lamble, Sarah. "Retelling Racialized Violence, Remaking White Innocence: The Politics of Interlocking Oppressions in Transgender Day of Remembrance" Sexuality Research and Social Policy. Springer-Verlag Publishing. March 2008. Online.

Miller, Quinn. “Television”. Transgender Studies Quarterly. 1 (1-2). 2014. 216-219. Web.

Morland, Iain. "Intersex" Transgender Studies Quarterly. 1(1-2). 2014. 111-115. Web.

Mulvey, Laura. "Visual Pleasure and Narrative Cinema." Film Theory and Criticism: Introductory Readings. Eds. Leo Braudy and Marshall Cohen. New York: Oxford UP. 1999: 833-44. Print.

Namaste, Viviane K. Invisible Lives: The Erasure of Transsexual and Transgendered People. Chicago, IL: University of Chicago Press, 2000. Print.

Namaste, Viviane K. Sex Change, Social Change: Reflections on Identity, Institutions, and Imperialism. Toronto: Women's Press, 2005. Print.

Prosser, Jay. Second Skins: The Body Narratives of Transsexuality. New York: Columbia University Press, 1998. Print.

Raymond, Janice G. The Transsexual Empire: The Making of the She-Male. New York: Teachers College Press, 1994. Print.

Raun, Tobias. Out Online: Trans Self-Representation and Community Building on YouTube. PhD Dissertation. Cultural Encounters, Department of Culture and Identity. Roskilde University. 2012.

Salamon, Gayle. Assuming a Body: Transgender and Rhetorics of Materiality. New York: Columbia University Press. 2010. Print.

Serano, Julia. Whipping Girl: A Transsexual Woman on Sexism and the Scapegoating of Femininity. Emeryville, CA: Seal, 2007. Print.

Smith, Stacy L., Marc Choueiti, and Katherine Pieper. Inclusion or Invisibility? Comprehensive Annenberg Report on Diversity in Entertainment. Rep. USC Annenberg, 22 Feb. 2016. Web. 6 Mar. 2016. $<$ http://annenberg.usc.edu/pages/ /media/MDSCI/CARDReport\%20FINAL\%202 2216.ash $x>$.

Steinmetz, Katy "Why Transgender People Are Being Murdered at a Historic Rate" TIME. 17 Aug, 2015. Web. 25 November 2015. http://time.com/3999348/transgender-murders-2015/

Stone, Sandy. "The Empire Strikes Back." The Transgender Studies Reader. Ed. Stryker, Susan and Stephen Whittle. Routledge Press. New York. 2006. 221-235. Print. 
Straayer, Chris. Deviant Eyes, Deviant Bodies: Sexual Re-Orientations in Film and Video. New York: Columbia University Press, 1996. Print.

Stryker, Susan. "My Words to Victor Frankenstein above the Village of Chamounix: Performing Transgender Rage" The Transgender Studies Reader. Ed. Susan Stryker and Stephen Whittle. Routledge Press. New York. 2006. 244-256. Print.

Stryker, Susan. Transgender History. Berkeley, CA: Seal Press, 2008. Print.

Sycamore, Mattilda Bernstein. Nobody Passes: Rejecting the Rules of Gender and Conformity. Emeryville, CA: Seal Press, 2006. Print.

Valentine, David. "I Went to Bed With My Own Kind Once: The Erasure of Desire In The Name of Identity" The Transgender Studies Reader. Ed. Susan Stryker and Stephen Whittle. Routledge Press. New York. 2006. 407-419. Print.

“What Is Intersex?” Intersex Society of North America. 1993. Web. 05 May 2016. $<\mathrm{http}: / /$ www.isna.org/faq/what_is_intersex $>$

Yuan, Jada. "How Jill Soloway is Bending Hollywood." Elle.com. Elle Magazine. 13 January 2015.Web. 8 March 2016.<http://www.elle.com/culture/moviestv/a25432/jill-soloway-transparent/> 


\section{Filmography}

52 Tuesdays. Dir. Sophie Hyde. Perf. Del Herbert-Jame, Tilda Cobham-Hervey. Closer Productions. 114 minutes. 2013. DVD.

About Ray. Dir. Gaby Dellal. Perf. Susan Sarandon, Elle Fanning, Naomi Watts. Big Beach Films. 2015. 87 minutes. DVD.

Albert Nobbs. Dir. Rodrigo Garcia. Perf. Glenn Close, Mia Wasikowska, Aaron TaylorJohnson. Mockingbird Pictures. 2011. 113 minutes. DVD.

The Adventures of Priscilla, Queen of the Desert. Dir. Stephan Elliott. Perf. Hugo Weaving, Guy Pearce, Terence Stamp. PolyGram Filmed Entertainment. 1994. 104 minutes. DVD.

Beautiful Boxer. Dir. Ekachai Uekrongtham. Perf. Asanee Suwan, Sorapong Chatree, Orn-Anong Panyawong. GMM Pictures Co. 2004. 118 minutes. DVD.

Boys Don't Cry. Dir. Kimberly Pierce. Perf. Hillary Swank, Chloe Sevigny, Peter Sarsgaard. Fox Searchlight Pictures. 1999. 118 minutes. DVD.

The Crying Game. Dir. Neil Jordan. Perf. Forest Whitaker, Stephen Rea. Palace Pictures \& Channel Four Films. 112 Minutes. 1992. DVD.

Dallas Buyers Club. Dir. Jean Marc Vallée. Perf. Matthew McConaughey, Jennifer Garner, Jared Leto. Truth Entertainment. 117 Minutes. 2013. DVD.

The Danish Girl. Dir. Tom Hooper. Perf. Alicia Vikander, Eddie Redmayne. Working Title Films. 119 Minutes. 2015. DVD.

Farewell My Concubine. Dir. Chen Kaige. Perf. Leslie Cheung, Fengi Zhang. Beijing Film Studio. 171 min. 1993. DVD.

HerStory. Creator Sydney Freeland. Perf. Angelica Ross, Jenn Richards. Indiegogo funded. 2015. Online. $<$ http://herstoryshow.com>

Jellyfish. Dir. Rosie Haber. Perf. Fui Lum, Alnashier Pajiji, Danica Reyes. 2014. 12 Min. Inside Out Festival Toronto 2015.

Paris is Burning. Dir. Jennie Livingston. Perf. André Christian, Dorian Corey. Art Matters Inc. 1991. 71 minutes. DVD. 
Romeos. Dir. Sabine Bernardi. Perf. Rick Okon, Maximilin Befort. Boogiefilms and Enigma Films. 94 minutes. 2011. DVD.

The Silence of the Lambs. Dir. Jonathan Demme. Perf. Anthony Hopkins, Jodie Foster. Orion Pictures Corp., 1991. DVD.

Tomboy. Dir. Céline Sciamma. Perf. Zoé Héran, Malonn Lévana. Hold Up Films. 82 Minutes. 2011. DVD.

Transamerica. Dir. Tucker, Duncan. Perf. Felicity Huffman, Kevin Zegers. 2005. Belladonna Productions. DVD.

Transparent. Creator Jill Soloway. Perf. Jeffrey Tambour, Amy Landecker, Jay Duplass. Amazon. 2014-2016. Online.

transparent. Dir. Jules Rosskam. Frameline Distribution. 2005. 61 Minutes. DVD.

XXY. Dir. Lucía Puenzo. Perf. Inés Efron, Ricardo Darín, Germán Palacios. DVD. Historias Cinematograficas Cinemania. 86 minutes. 2007. DVD. 